\title{
Allylboration of Ketones and Imines with a Highly Reactive Bifunctional Allyl Pinacolatoboronate Reagent
}

Jiaming Liu, Xinbo Tong and Ming Chen*

Department of Chemistry and Biochemistry

Auburn University

E-mail: mzc0102@auburn.edu

Supporting Information: ${ }^{1} \mathrm{H}$ and ${ }^{13} \mathrm{C}$ Spectra of New Compounds 

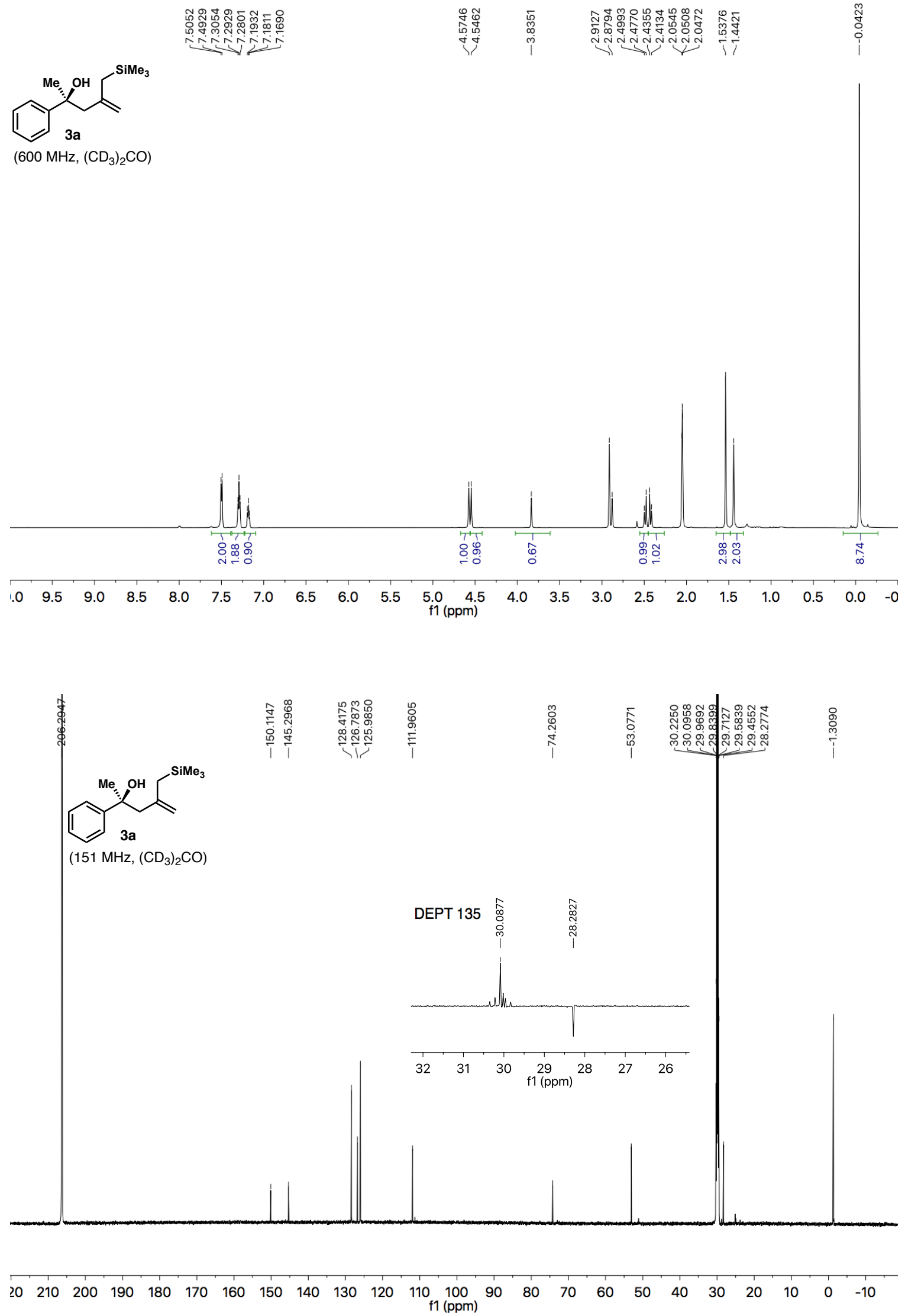

SI-2 

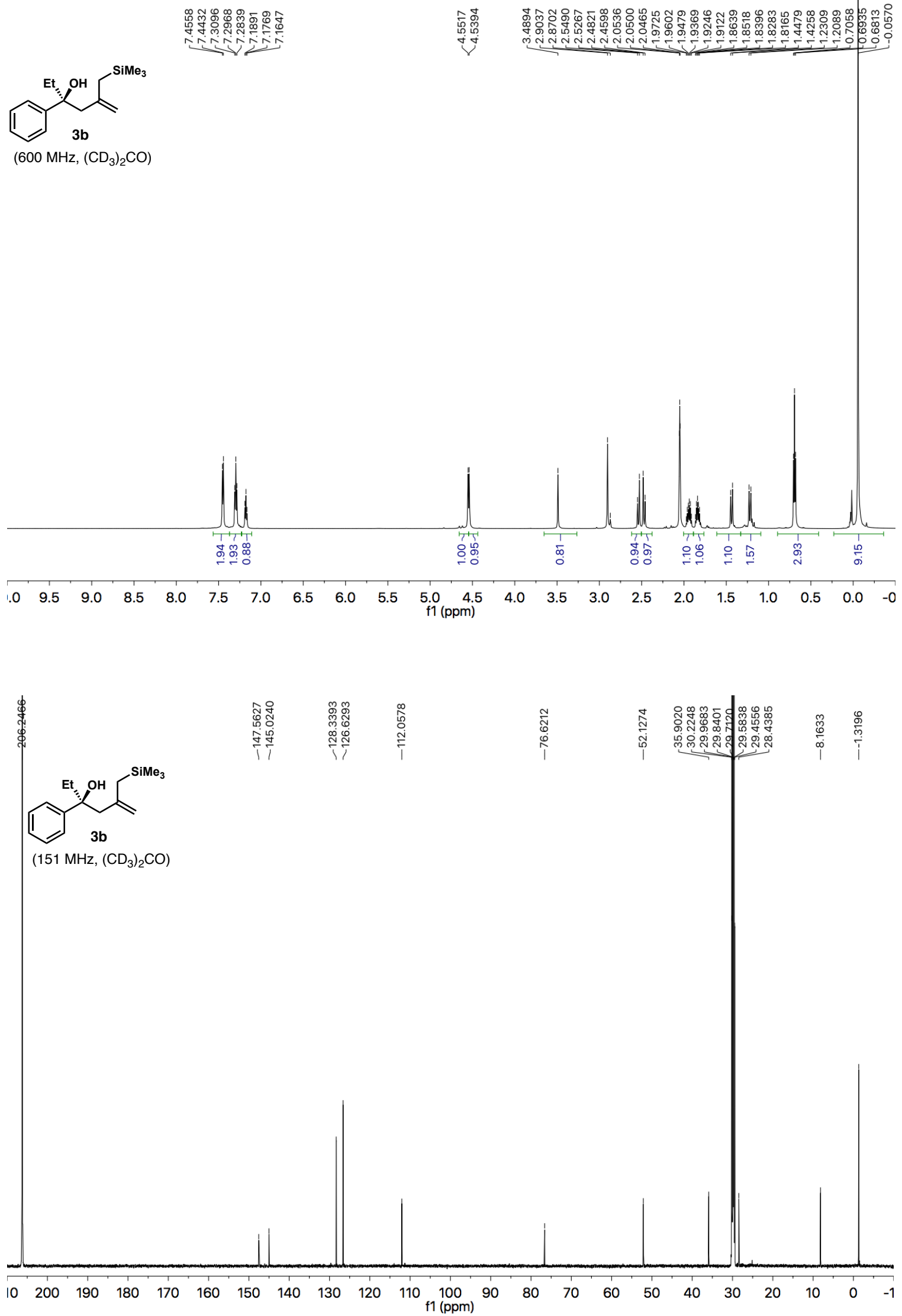

SI-3 

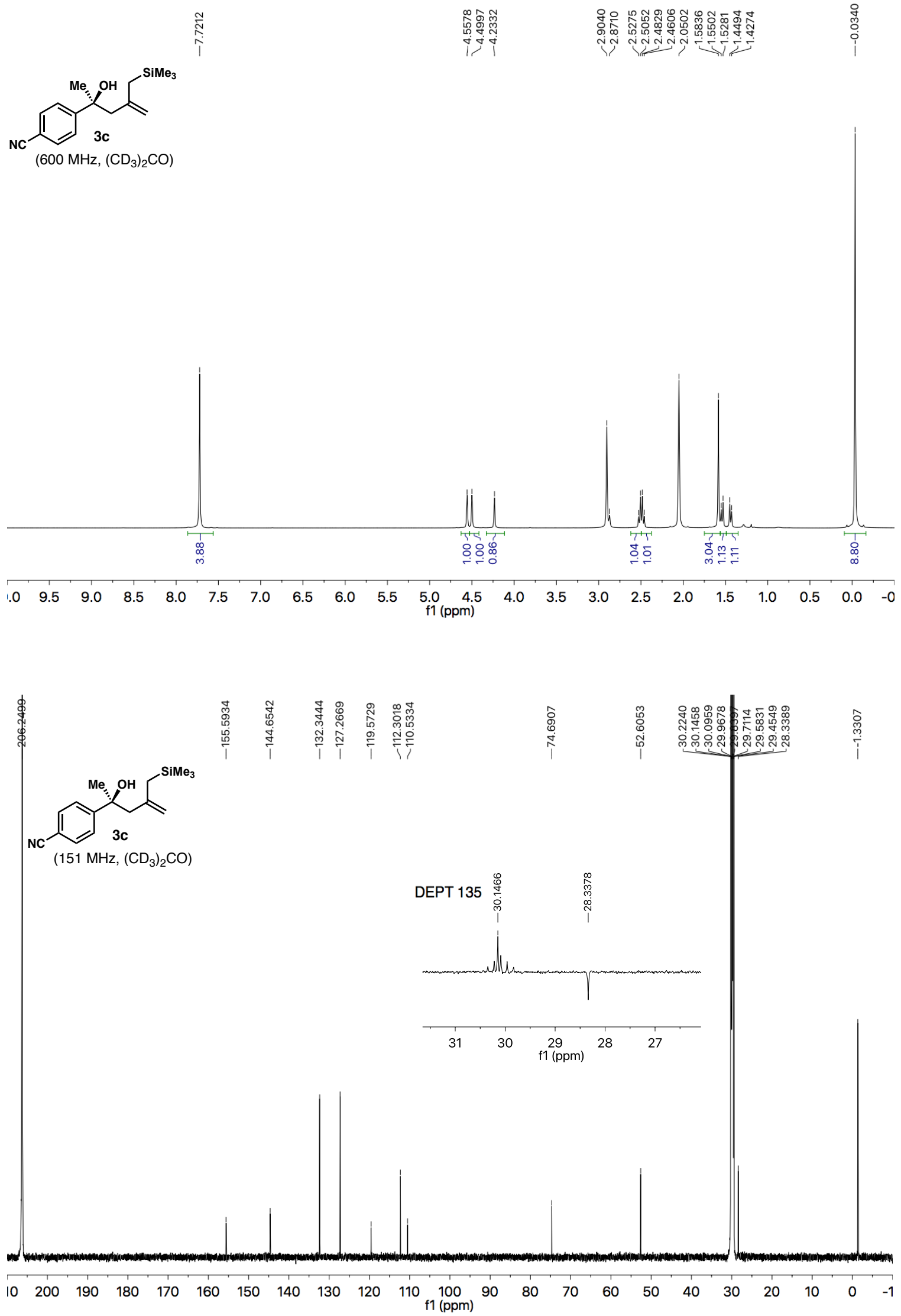

SI-4 

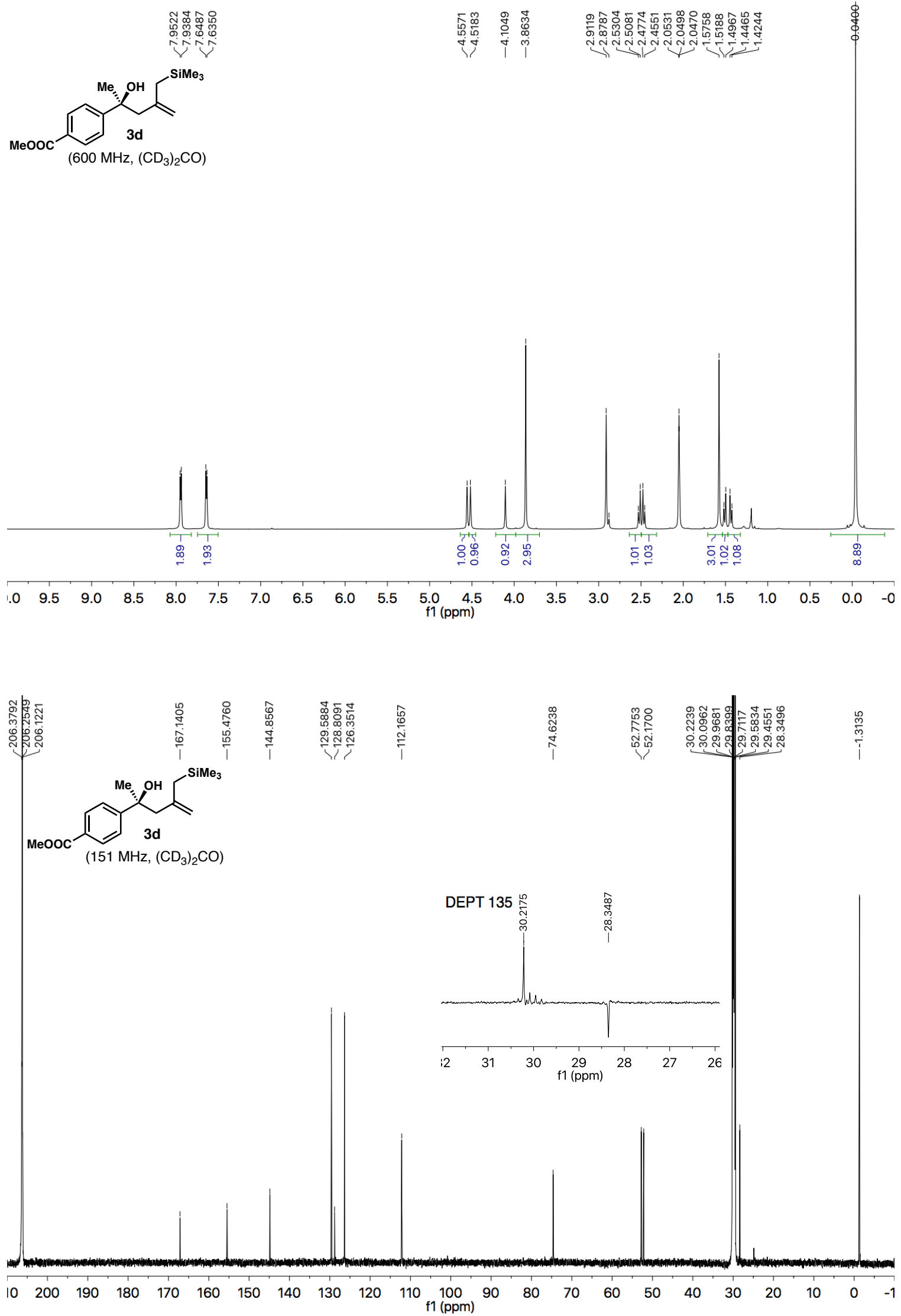

SI-5 

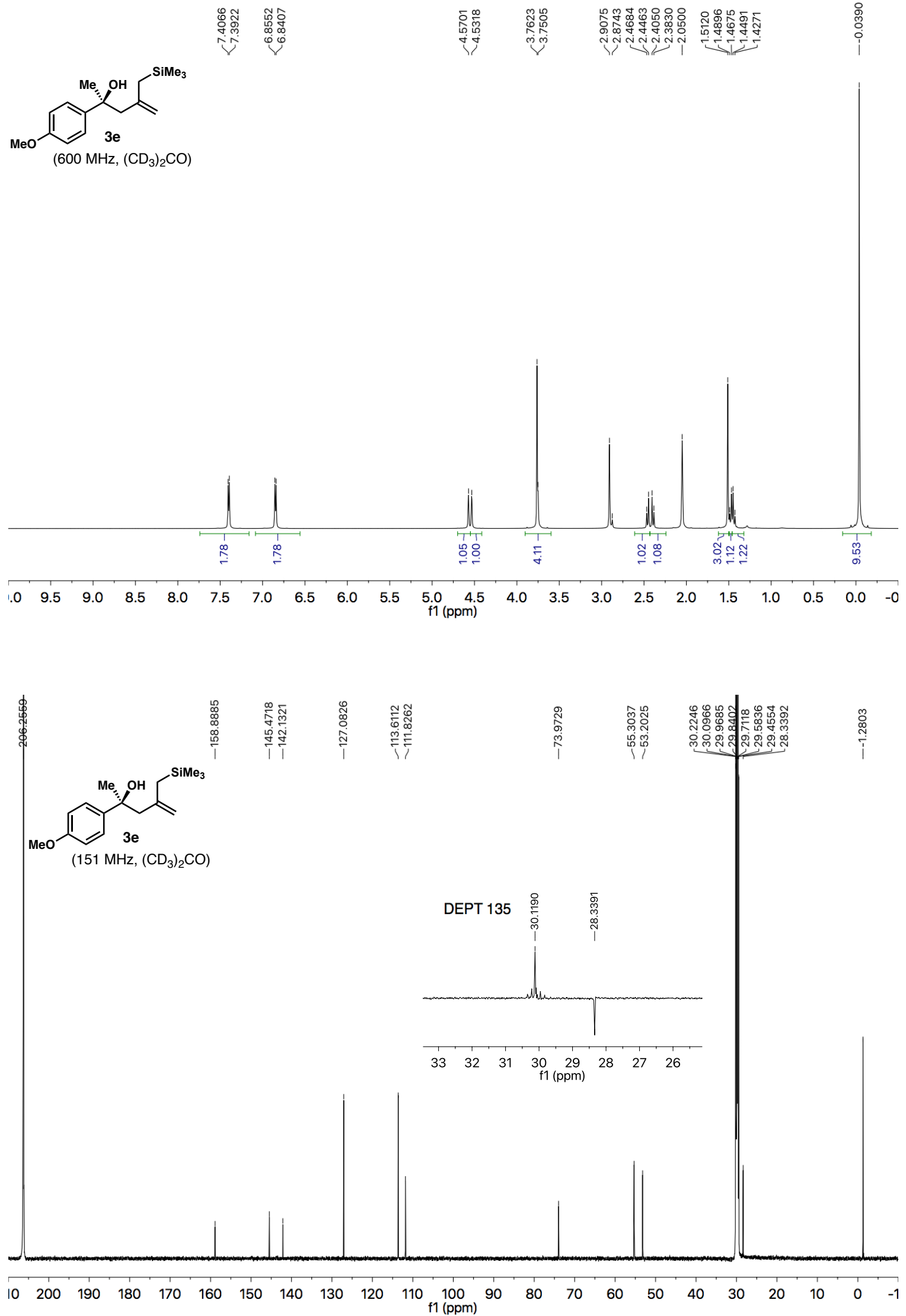

SI-6 

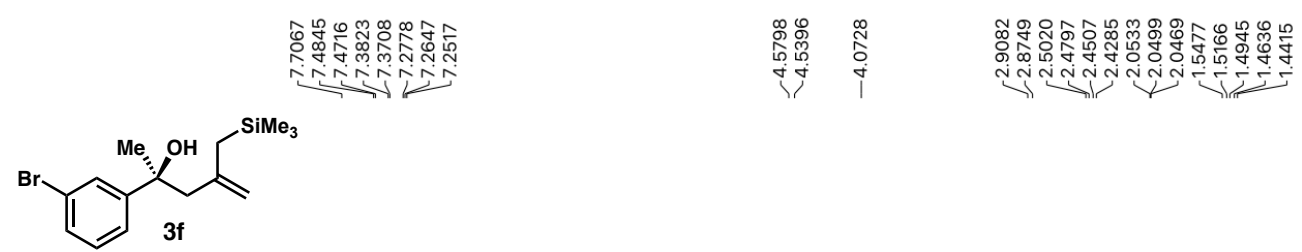

$\left(600 \mathrm{MHz},\left(\mathrm{CD}_{3}\right)_{2} \mathrm{CO}\right)$
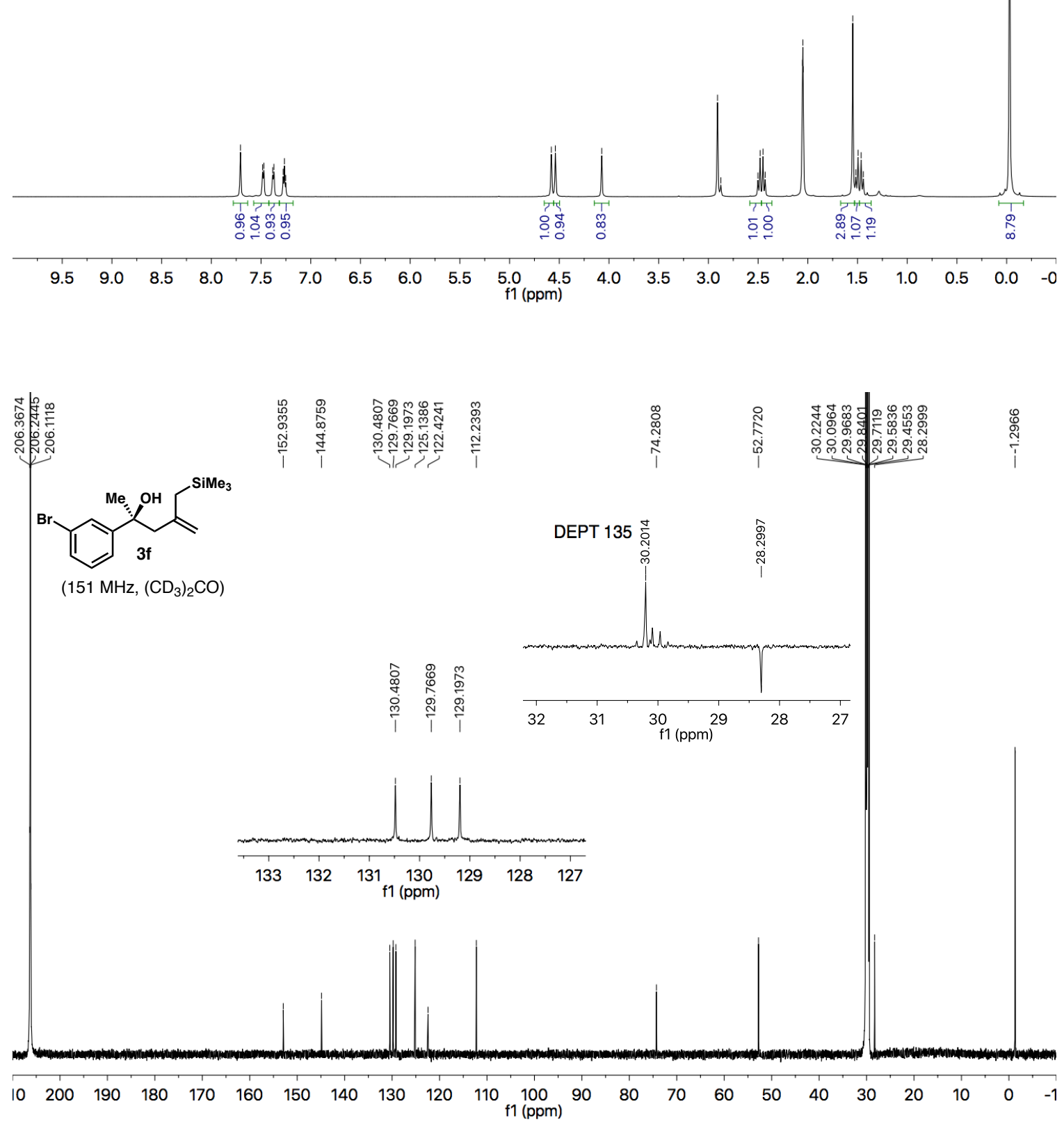

SI-7 


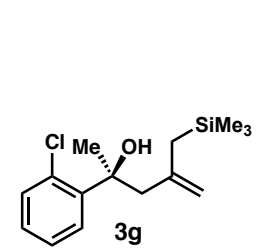

$\left(600 \mathrm{MHz},\left(\mathrm{CD}_{3}\right)_{2} \mathrm{CO}\right)$
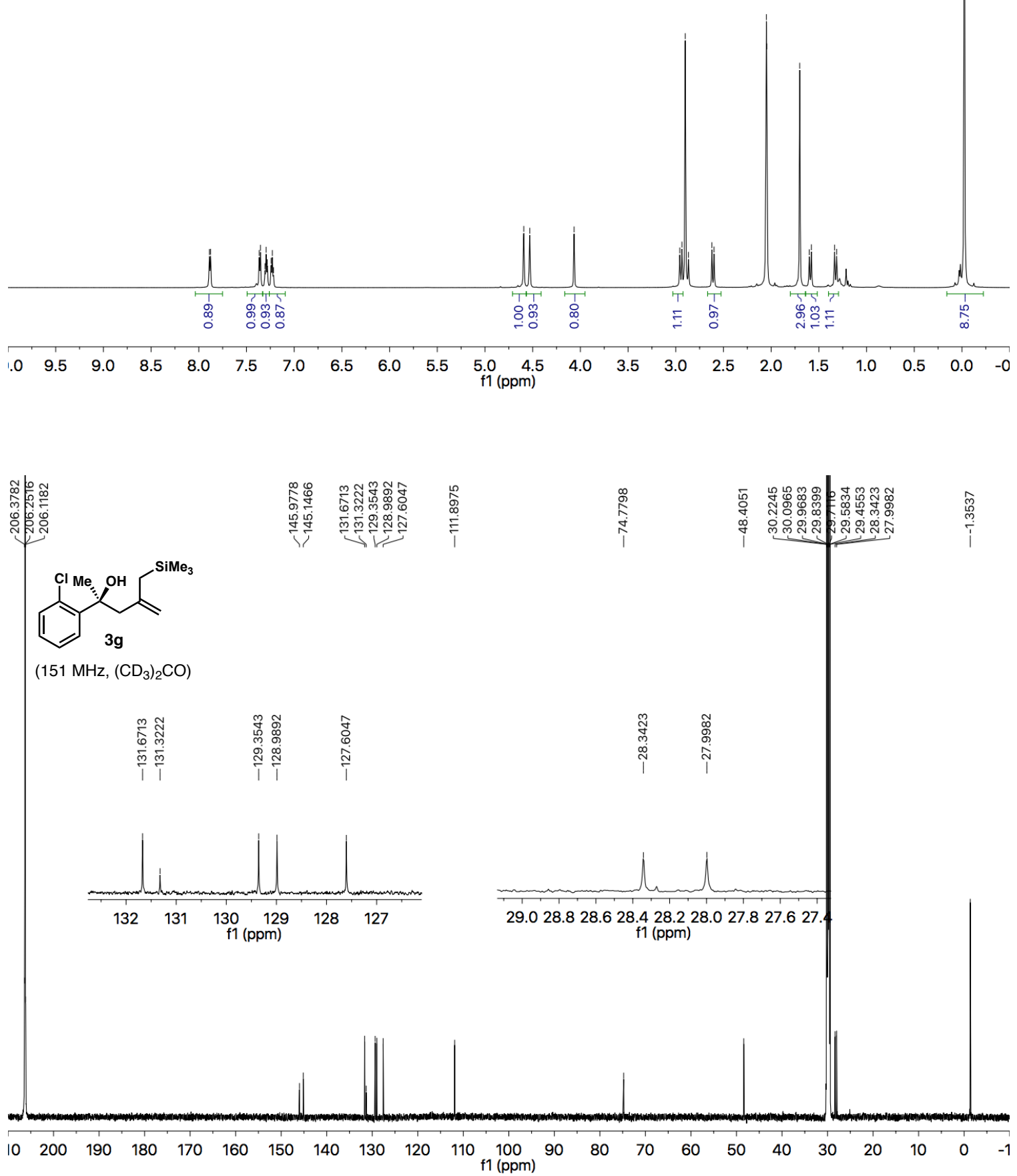

SI-8 

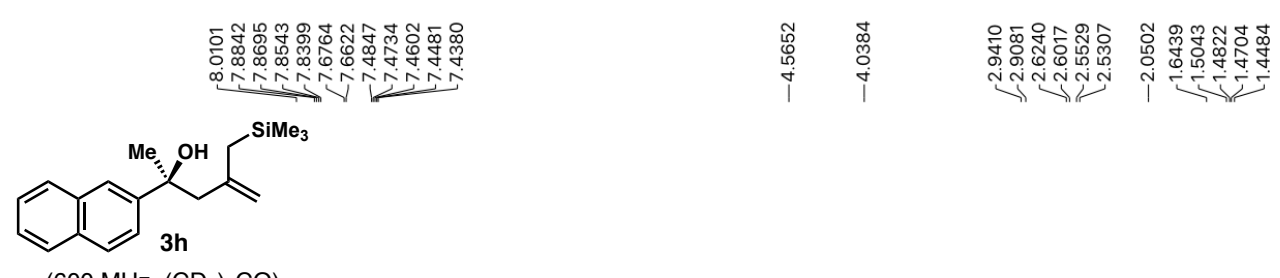

$\left(600 \mathrm{MHz},\left(\mathrm{CD}_{3}\right)_{2} \mathrm{CO}\right)$
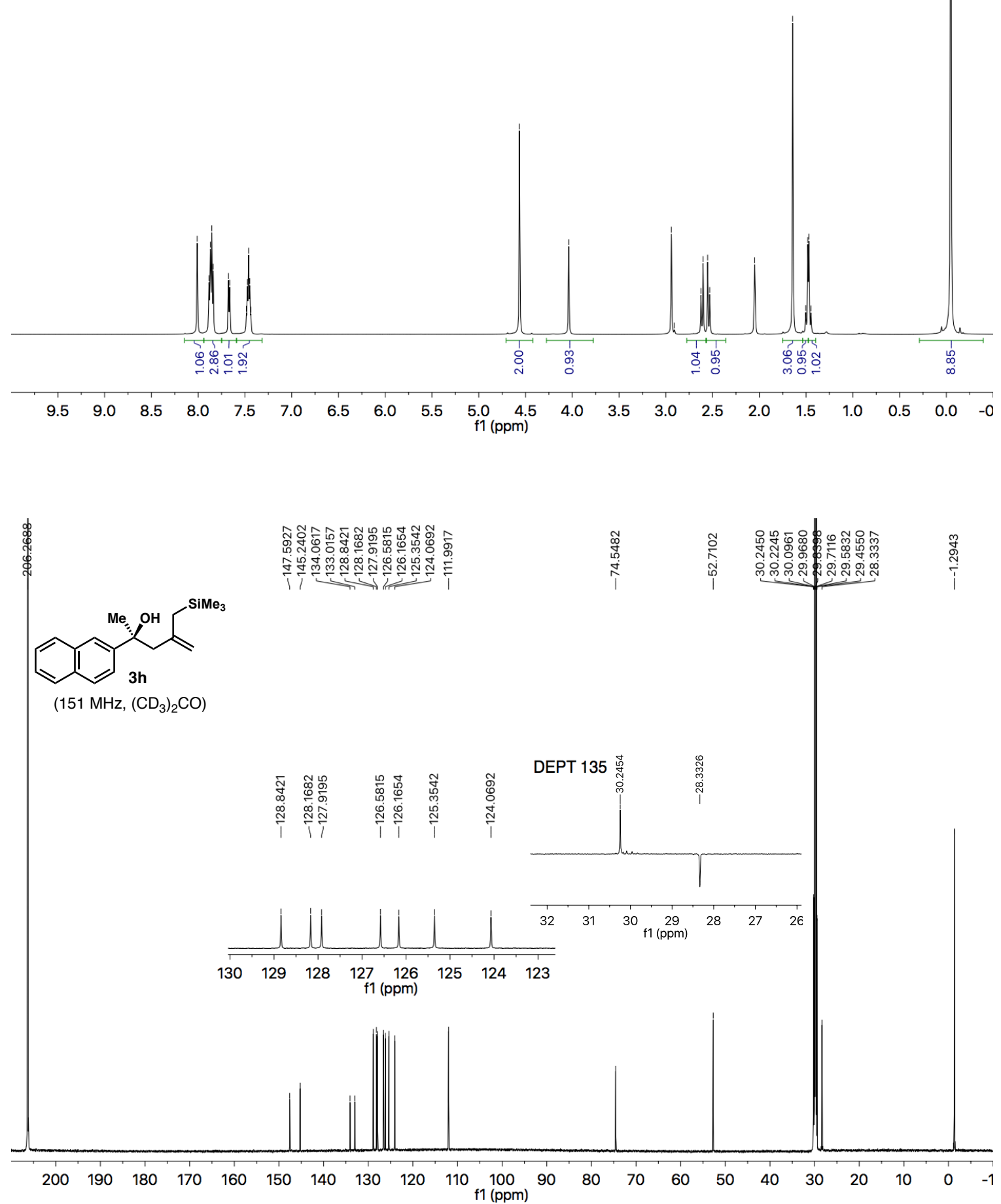

SI-9 

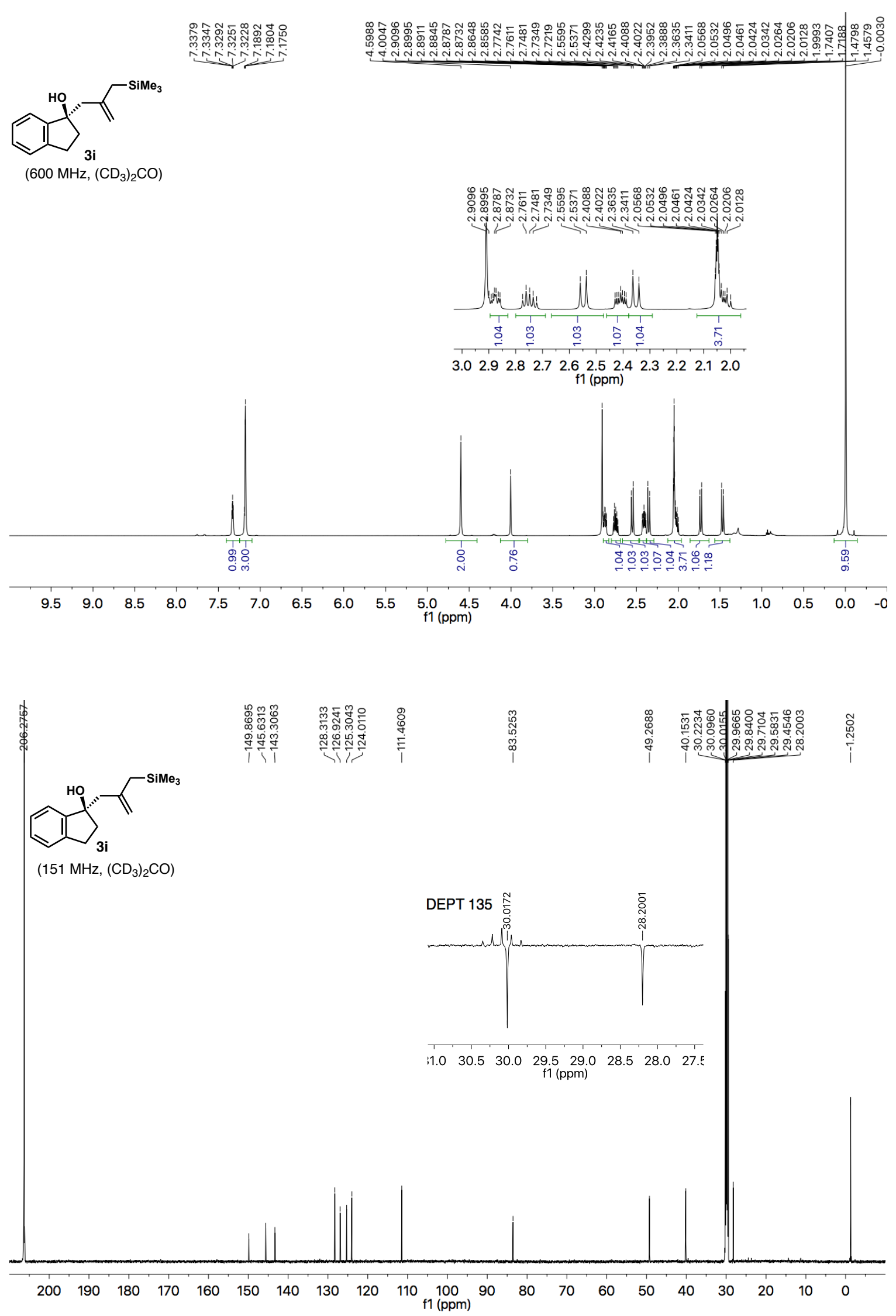

SI-10 

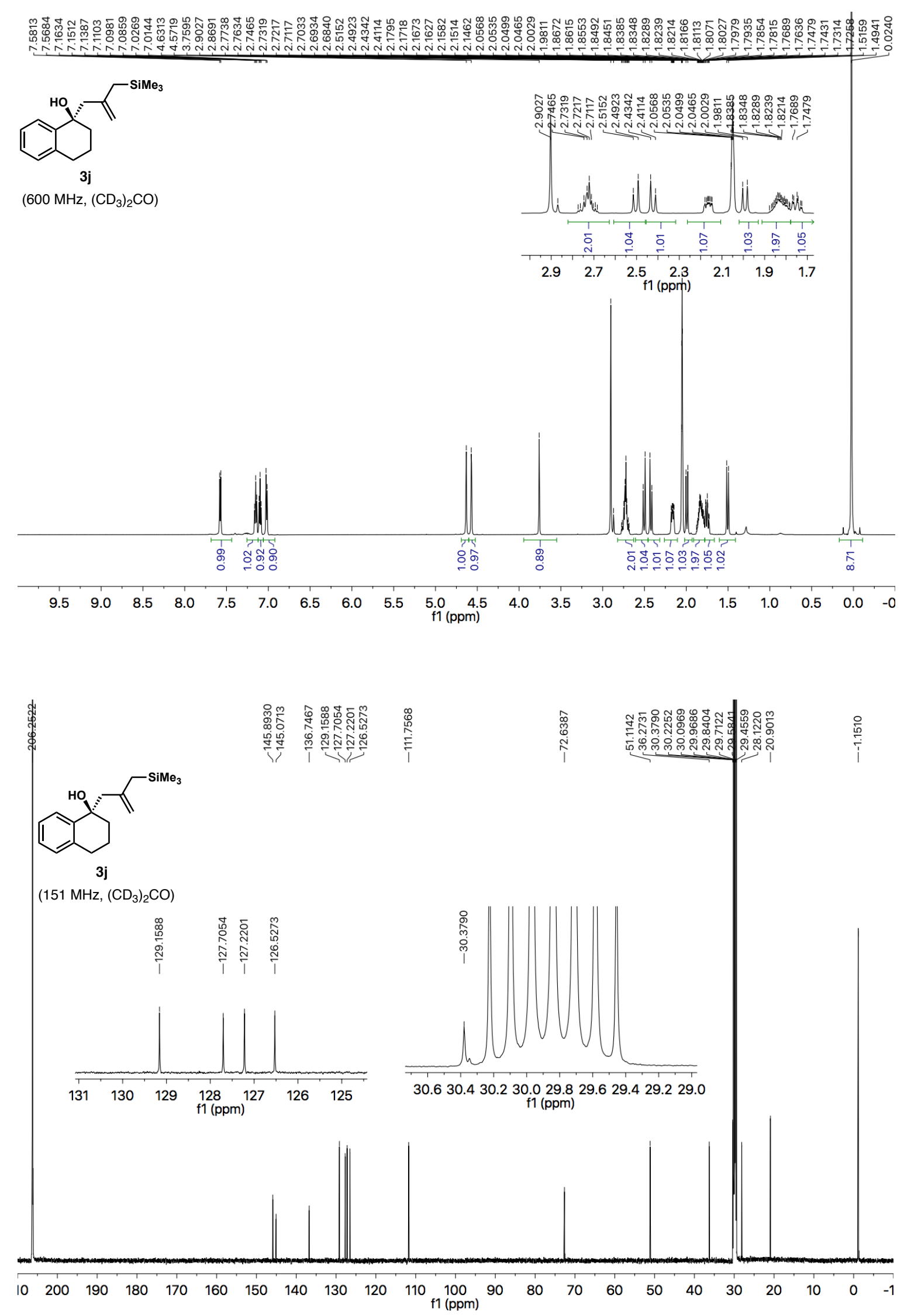

SI-11 

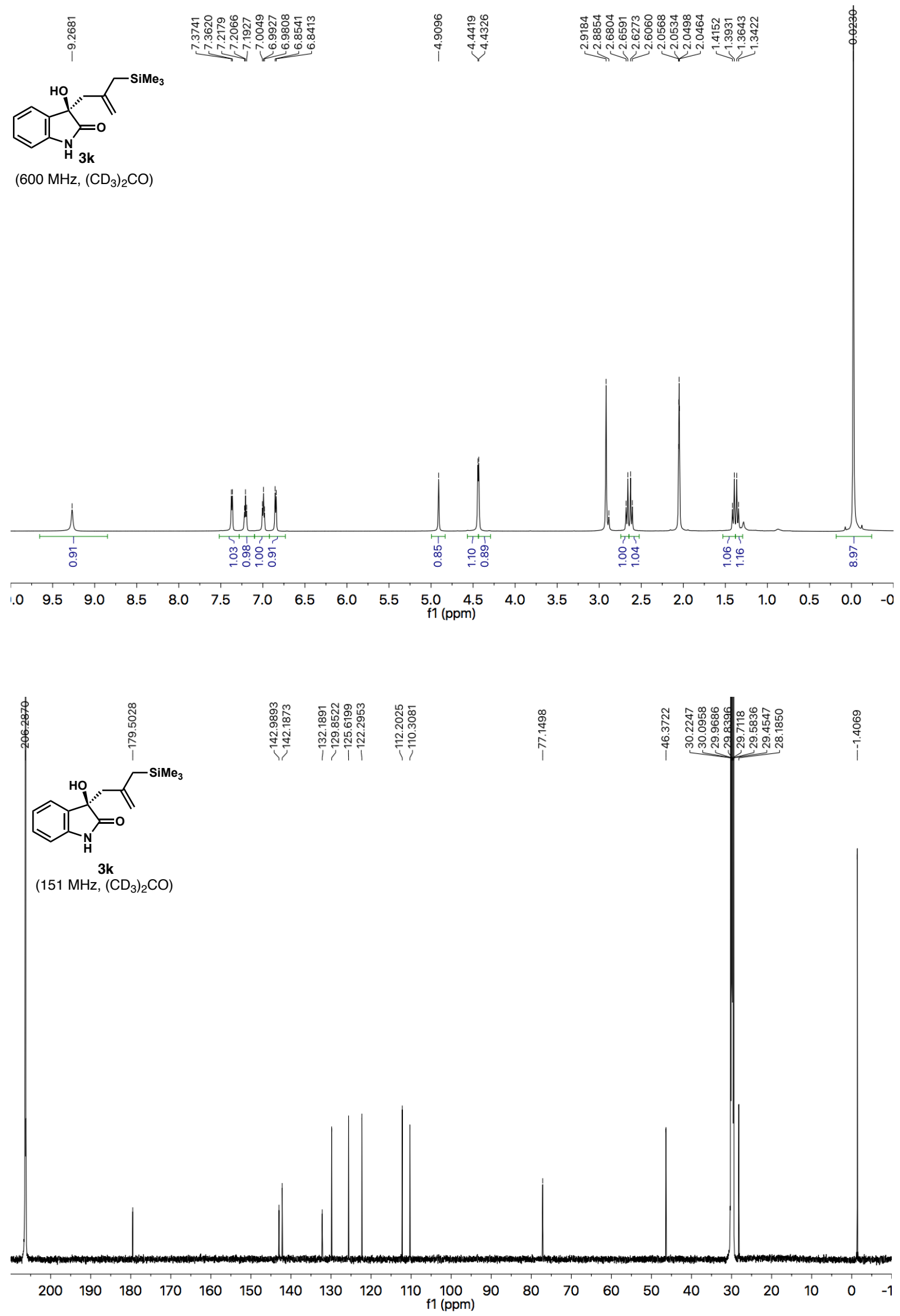

SI-12 

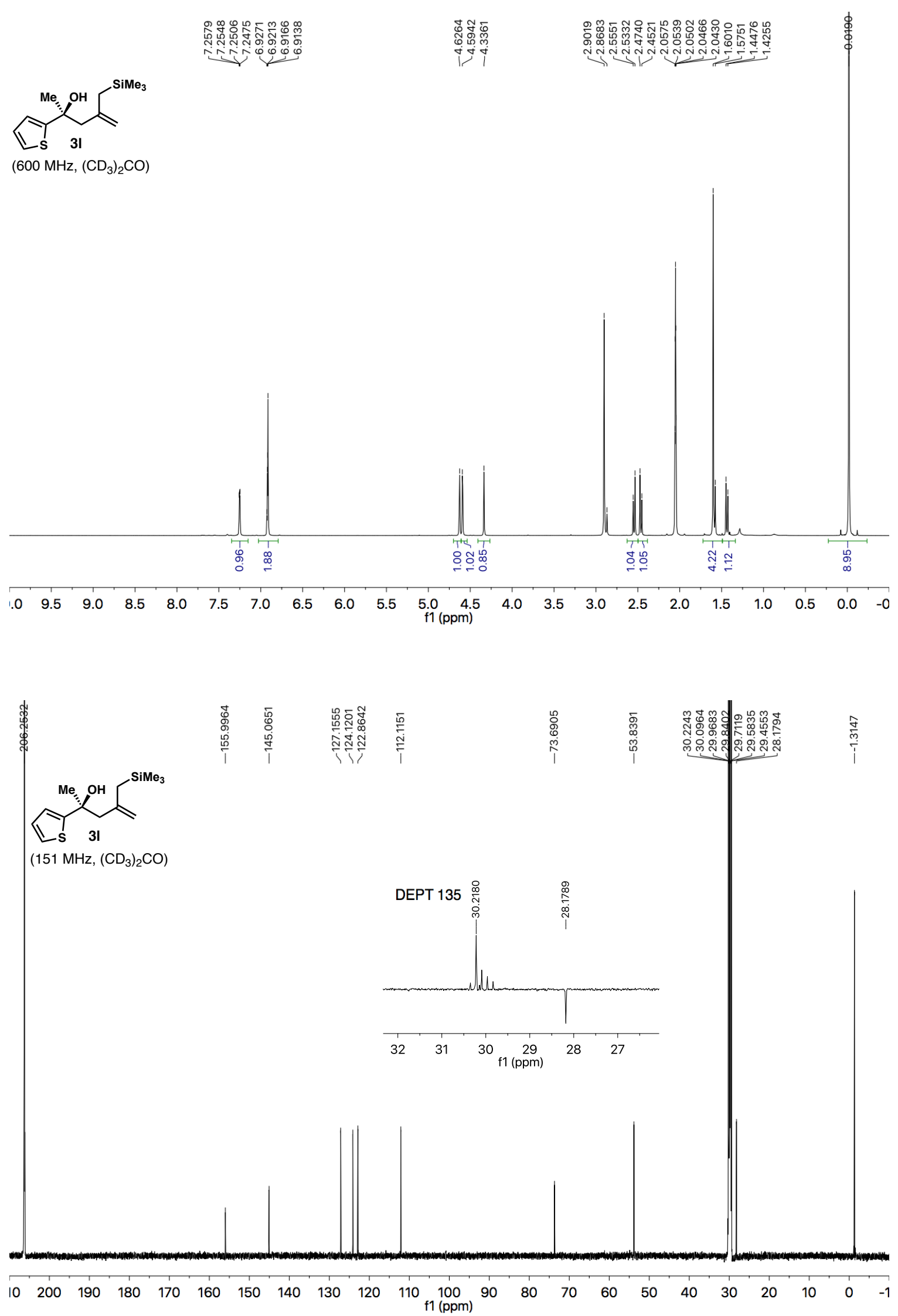

SI-13 

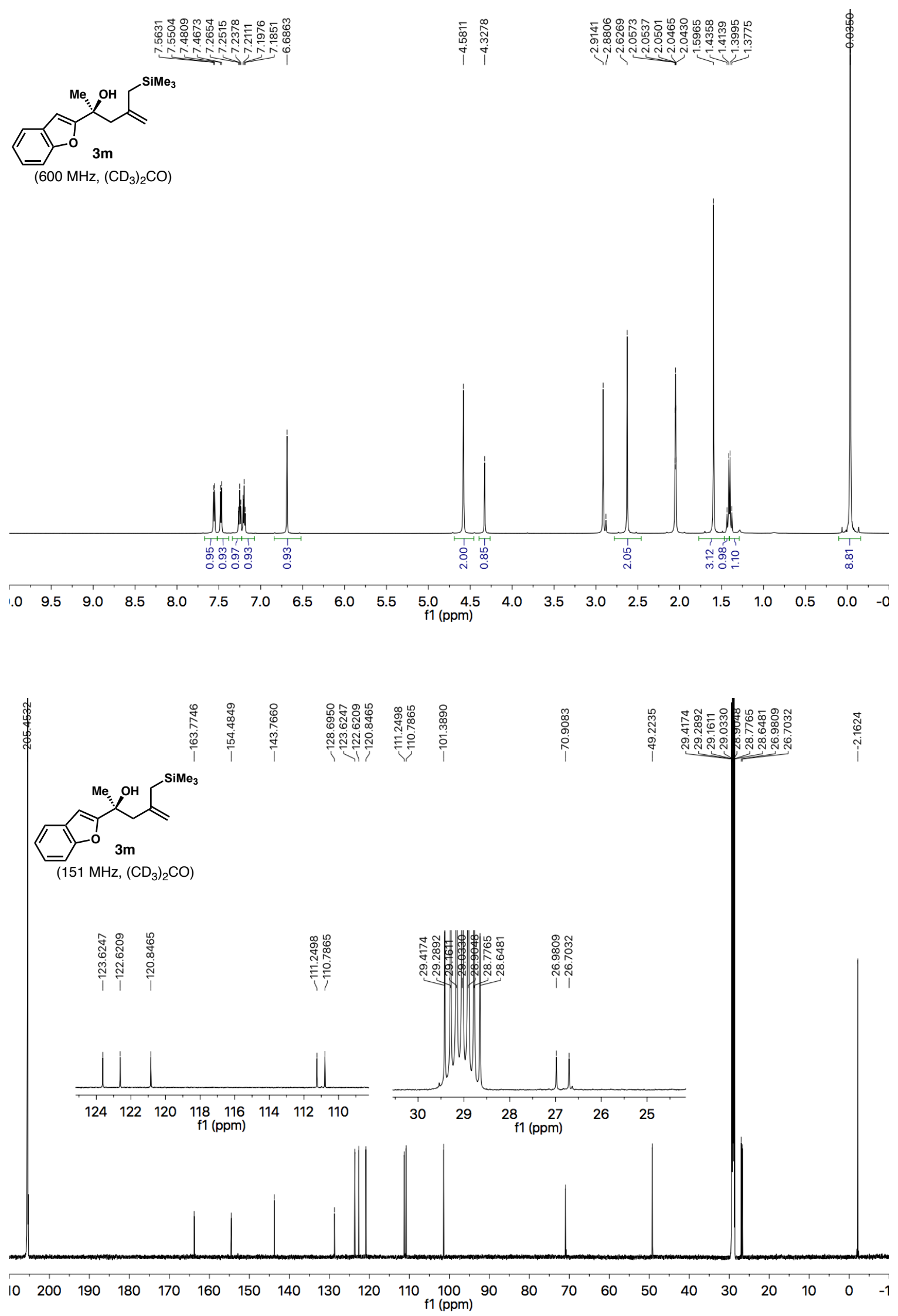

SI-14 

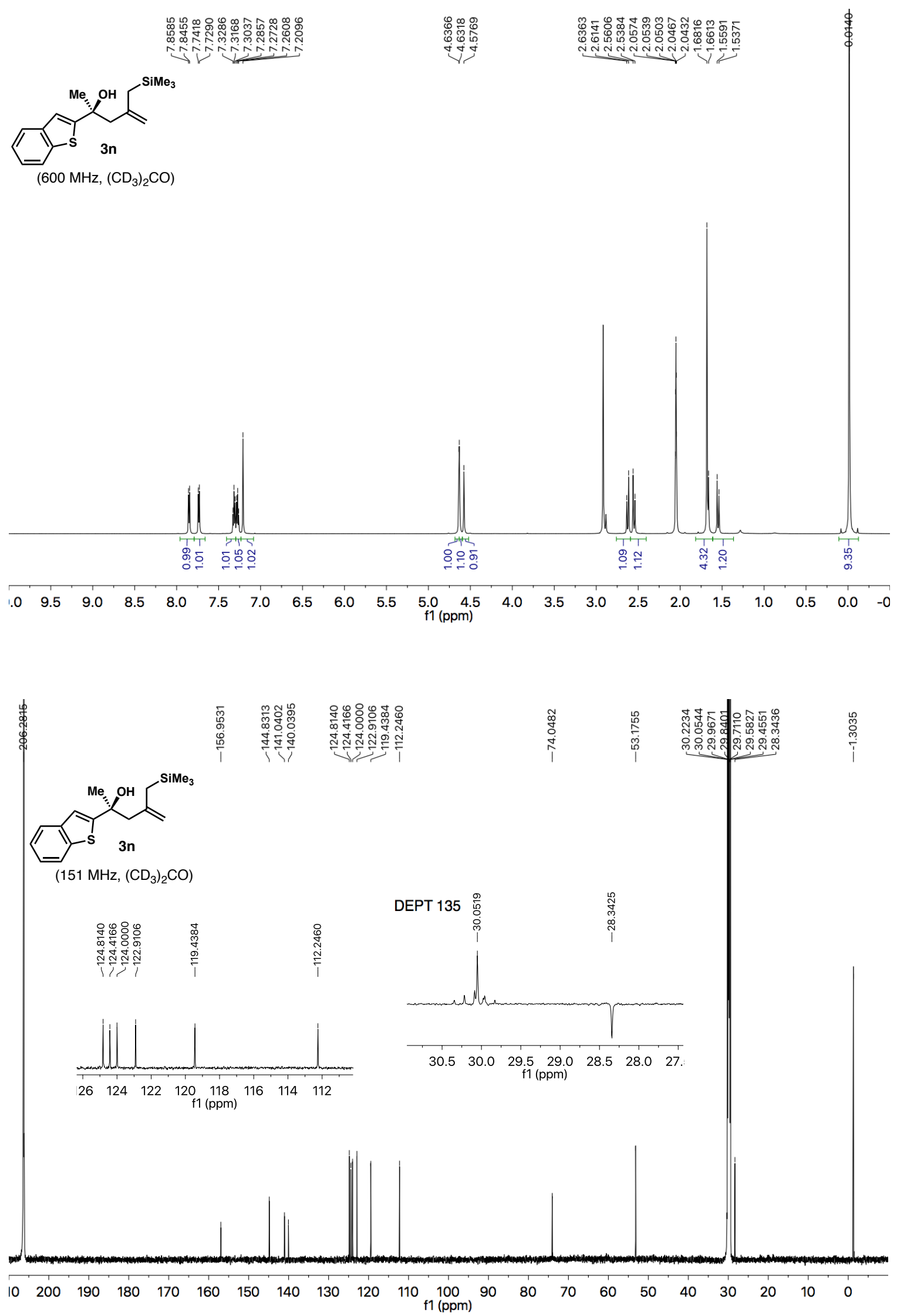

SI-15 

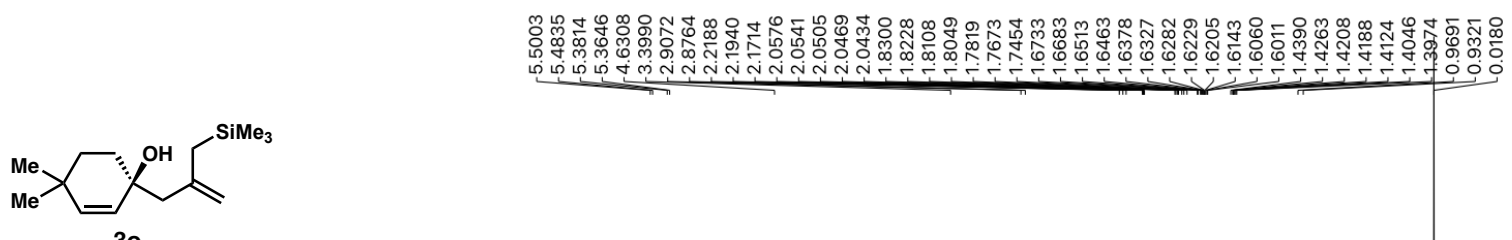

$\left(600 \mathrm{MHz},\left(\mathrm{CD}_{3}\right)_{2} \mathrm{CO}\right)$
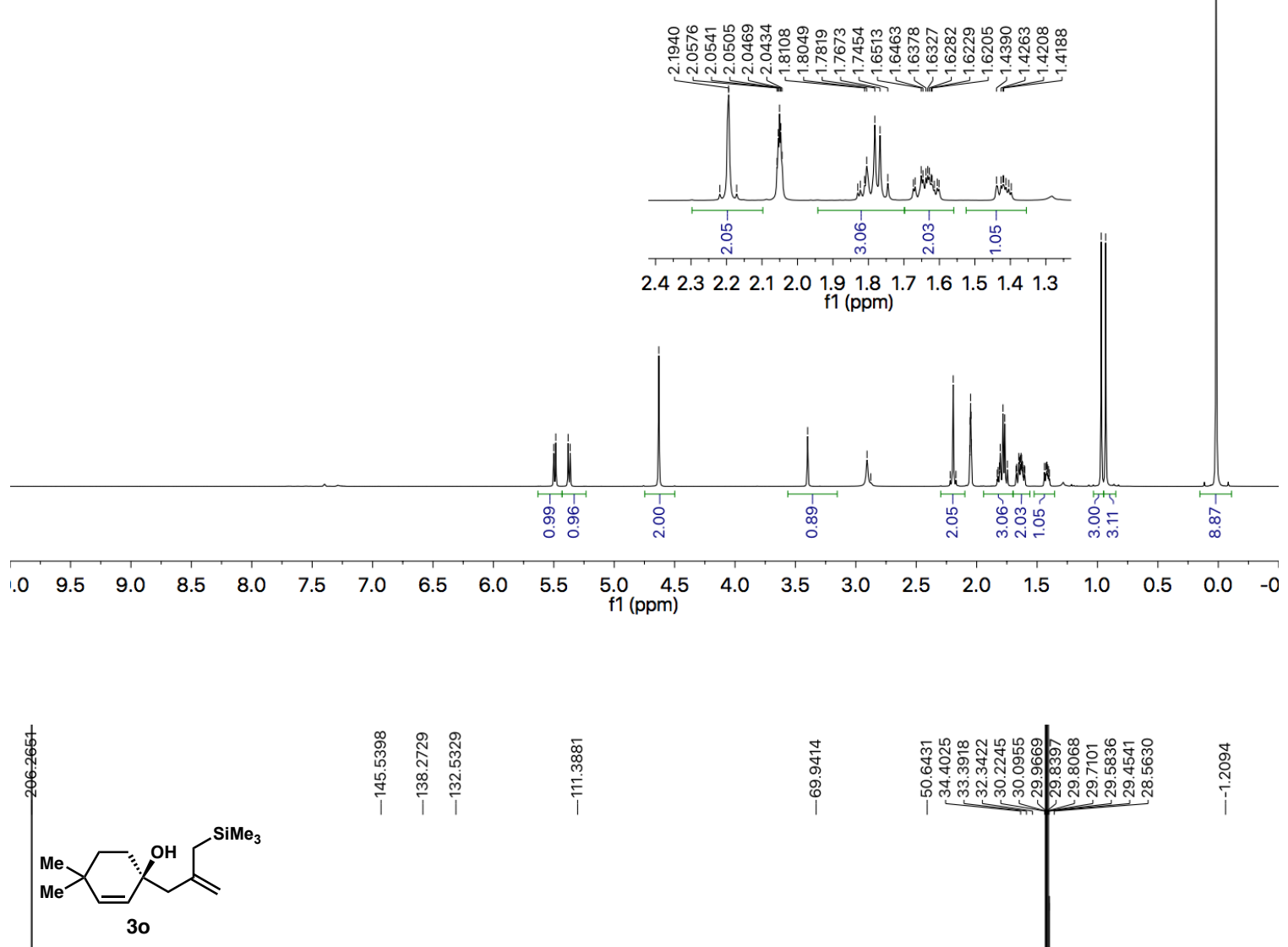

(151 MHz, $\left.\left(\mathrm{CD}_{3}\right)_{2} \mathrm{CO}\right)$
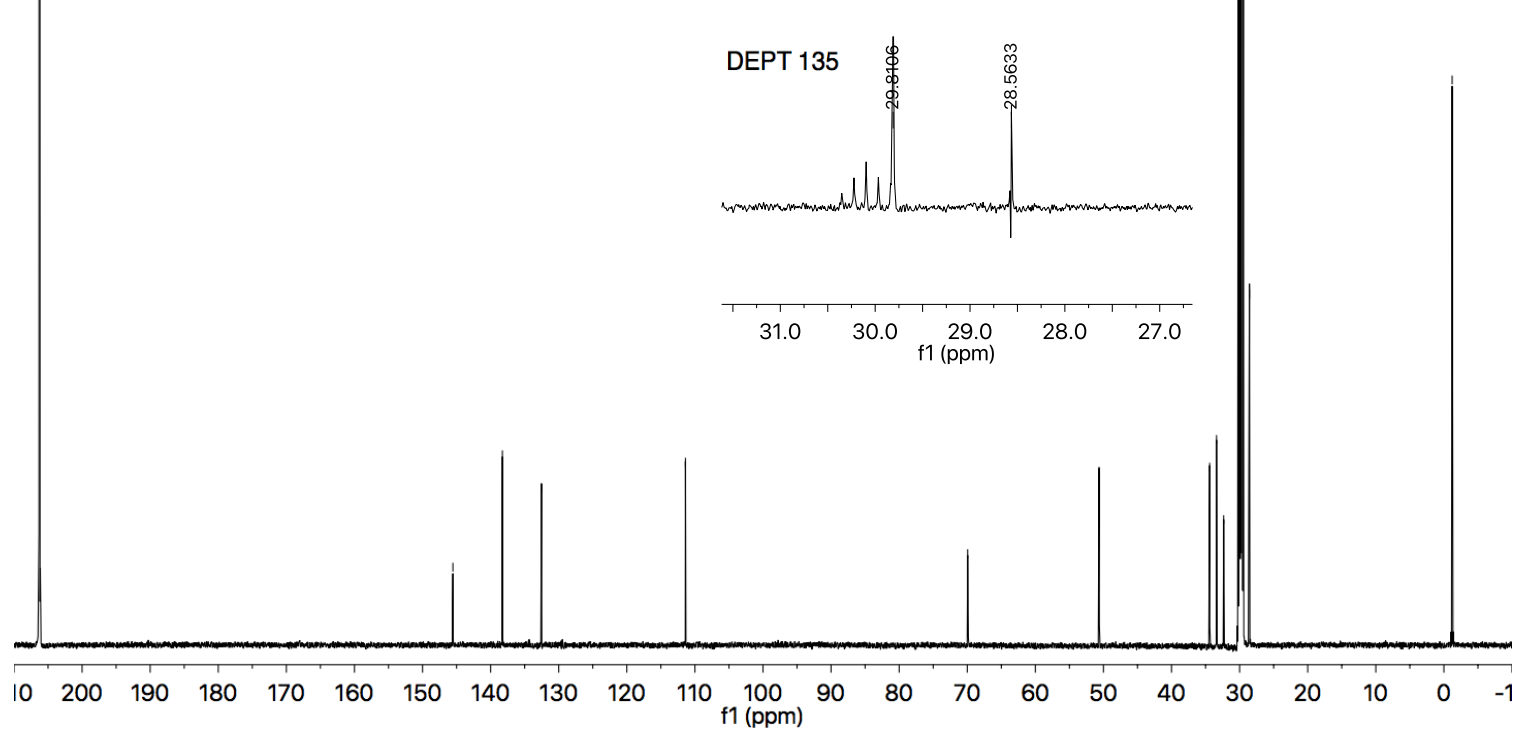

SI-16 

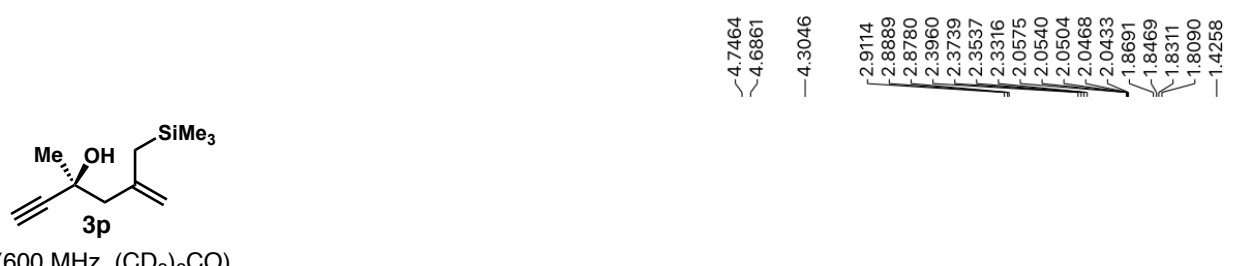

$\left(600 \mathrm{MHz},\left(\mathrm{CD}_{3}\right)_{2} \mathrm{CO}\right)$
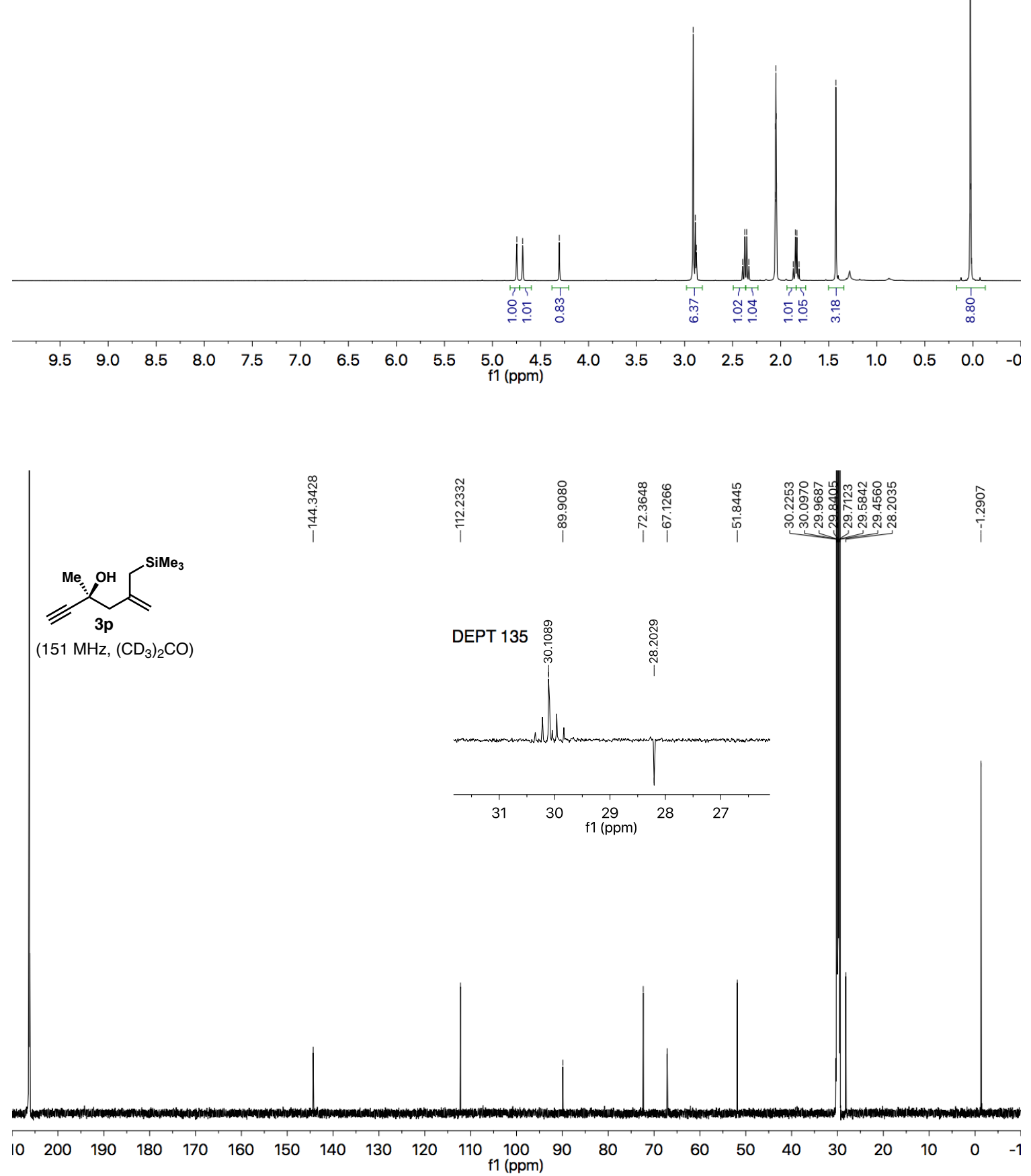

SI-17 

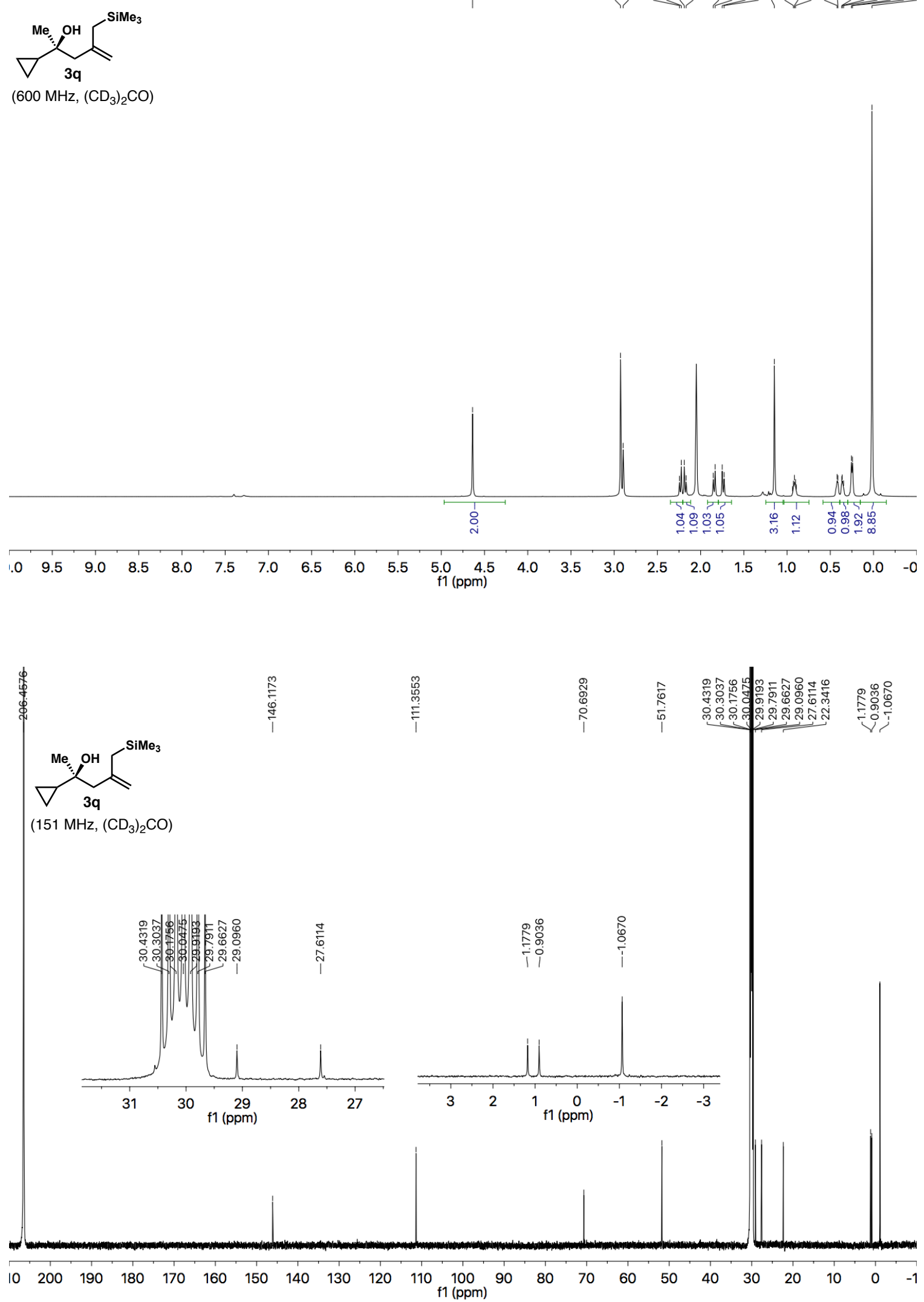

SI-18 

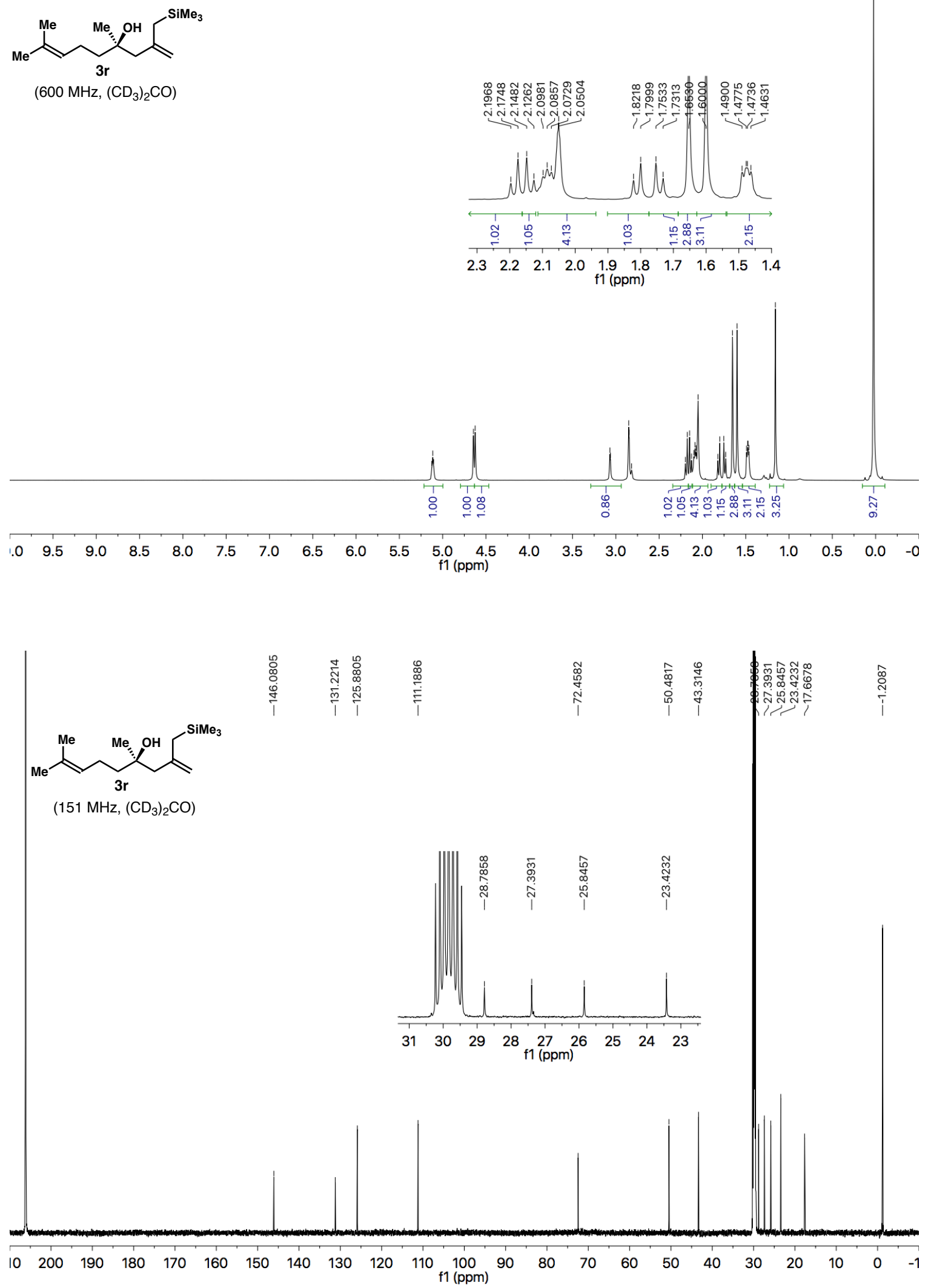

SI-19 

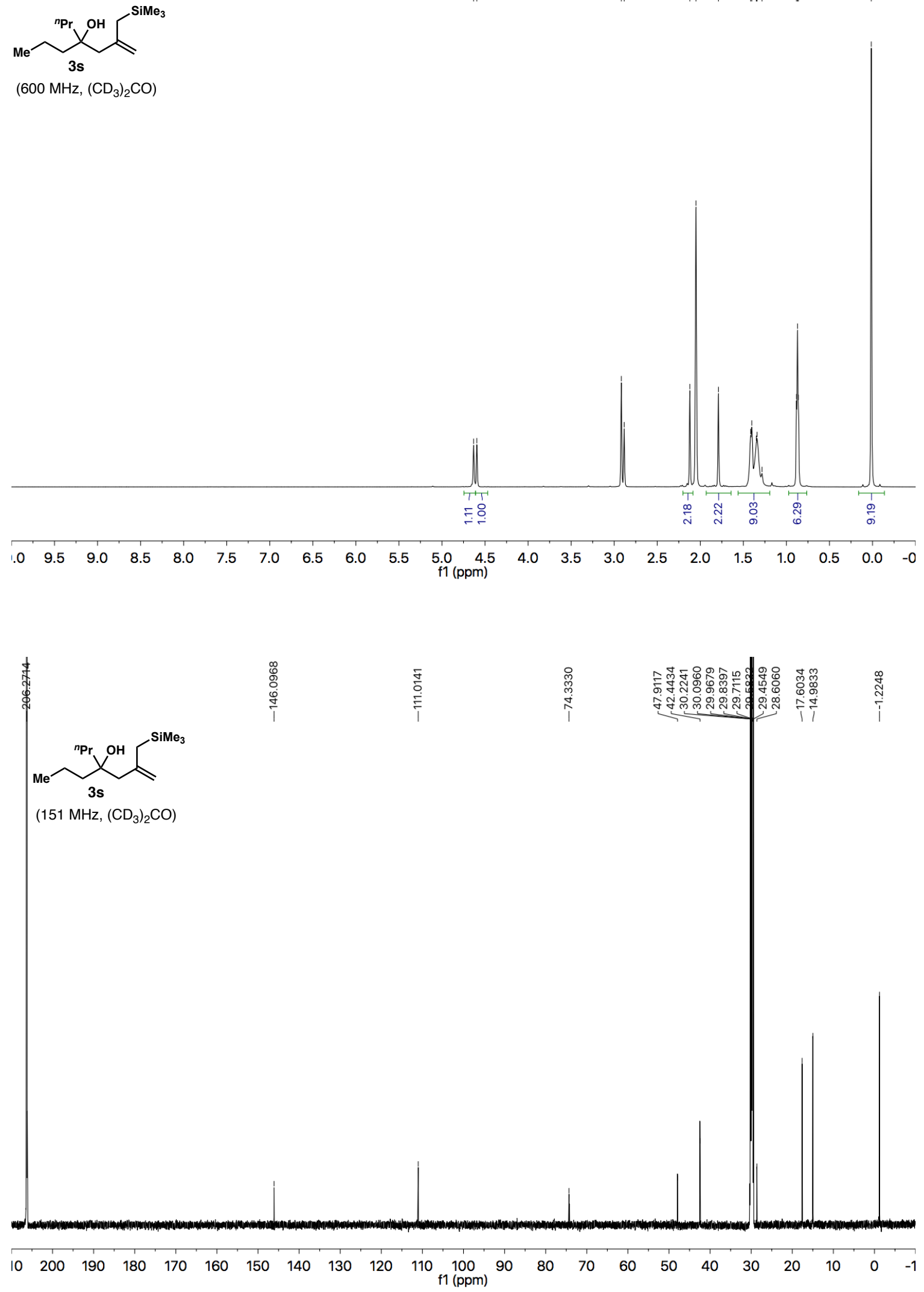


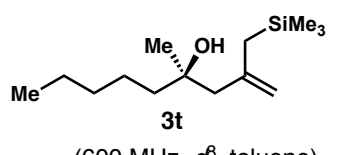

(600 MHz, $d^{8}$-toluene)
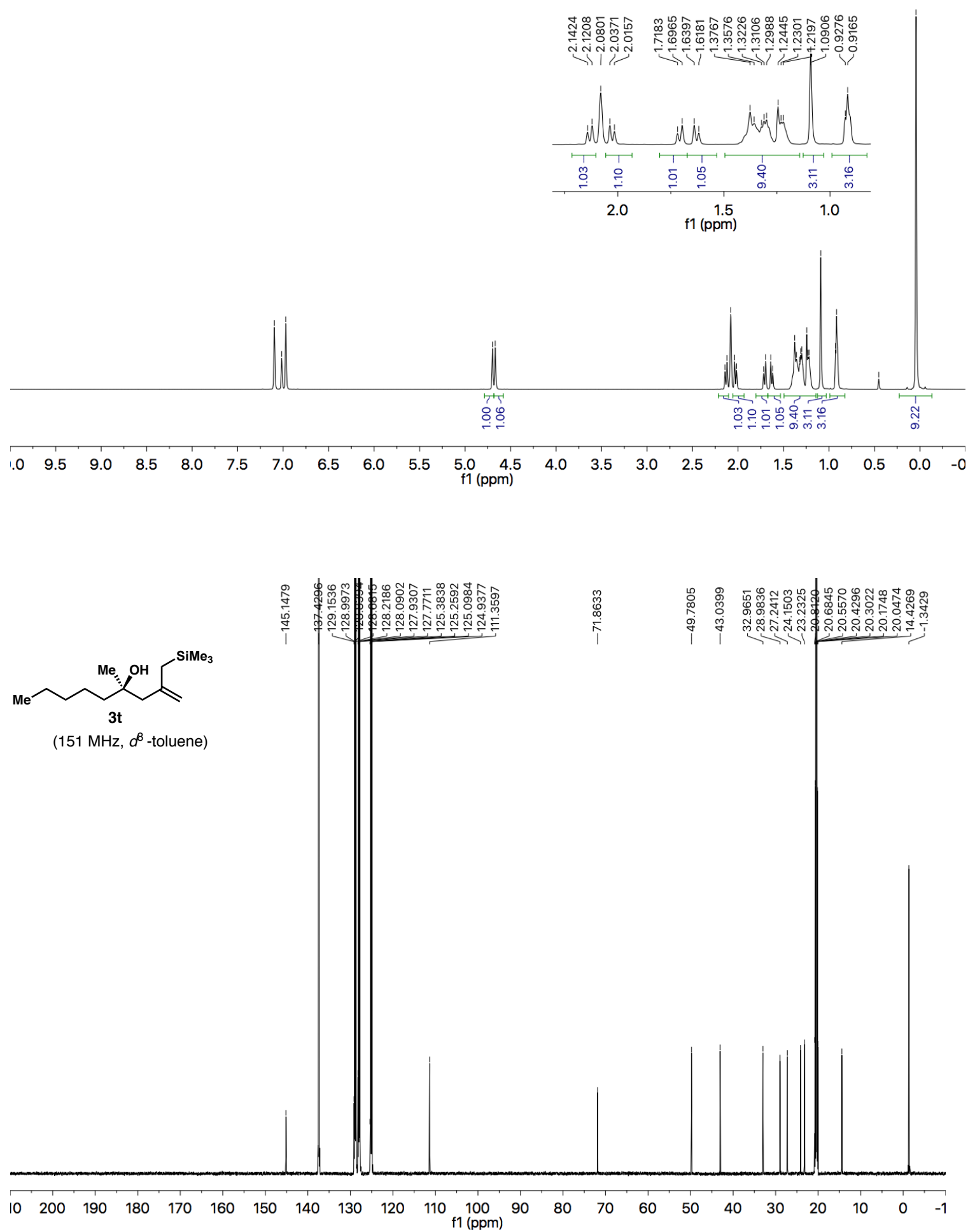


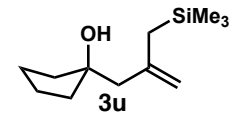

(400 MHz, $\left.\left(\mathrm{CD}_{3}\right)_{2} \mathrm{CO}\right)$
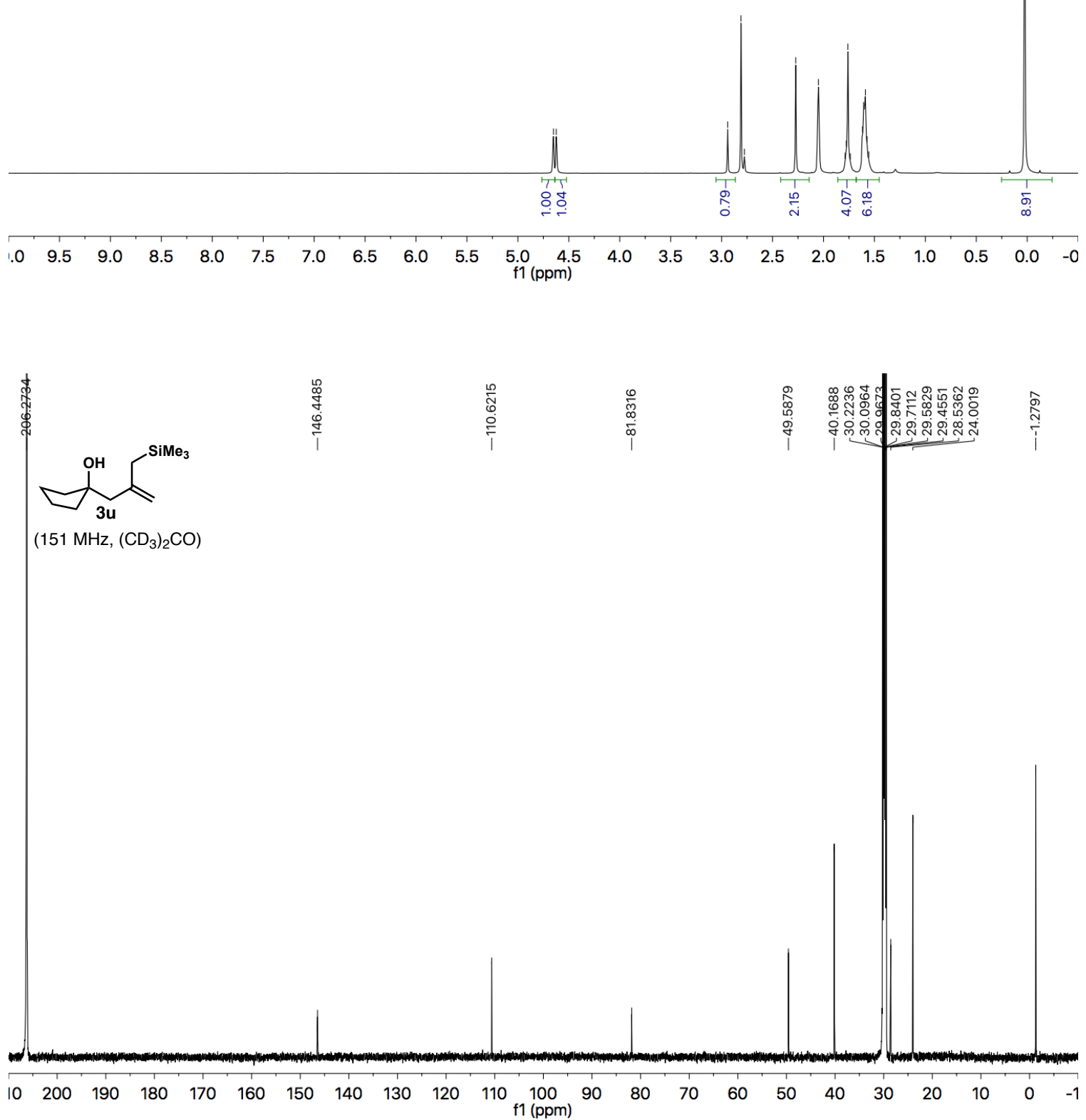

SI-22 


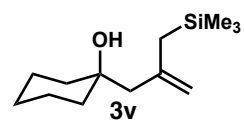

(400 MHz, $\left.\left(\mathrm{CD}_{3}\right)_{2} \mathrm{CO}\right)$
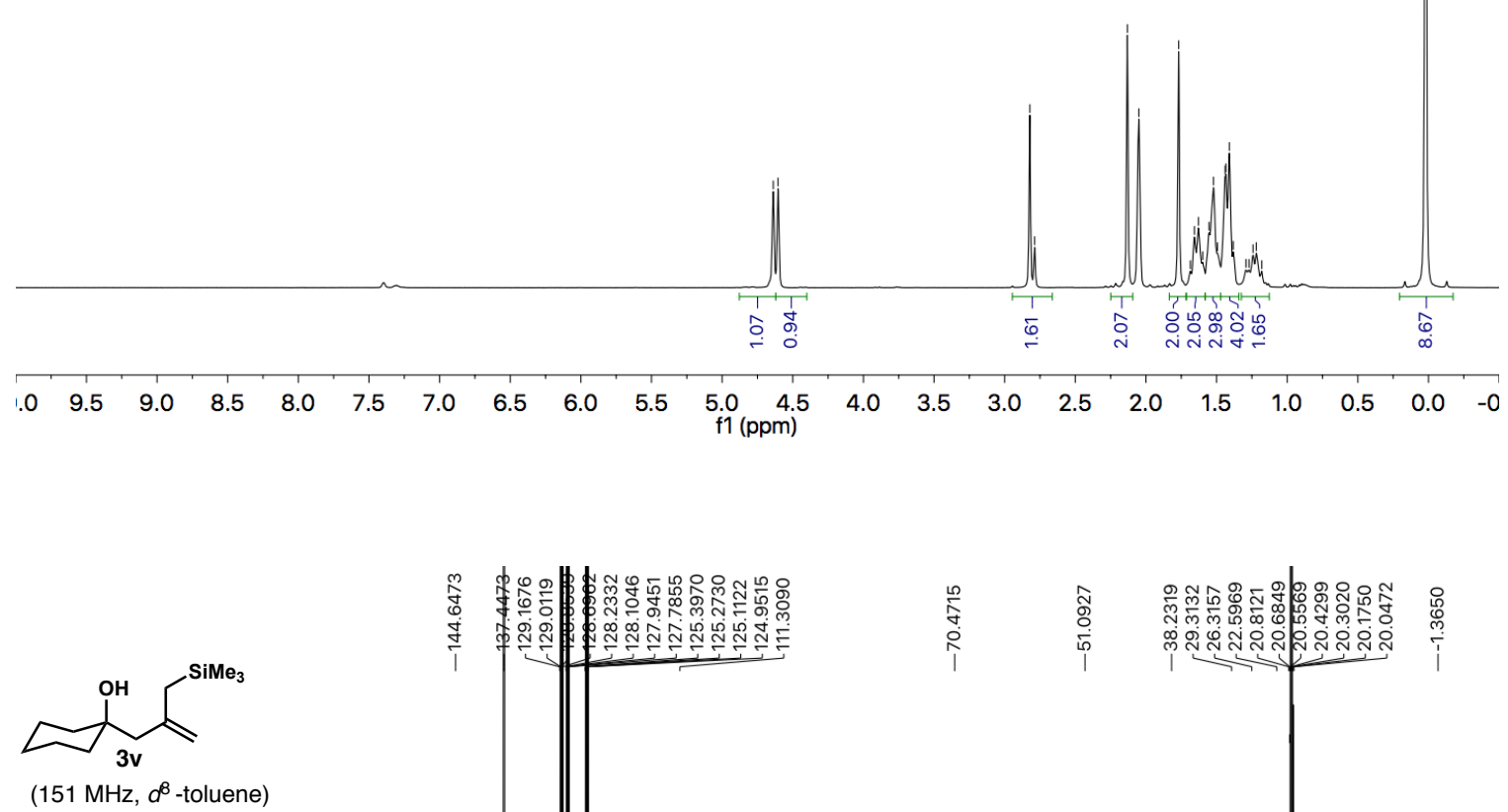

(151 MHz, $d^{8}$-toluene)

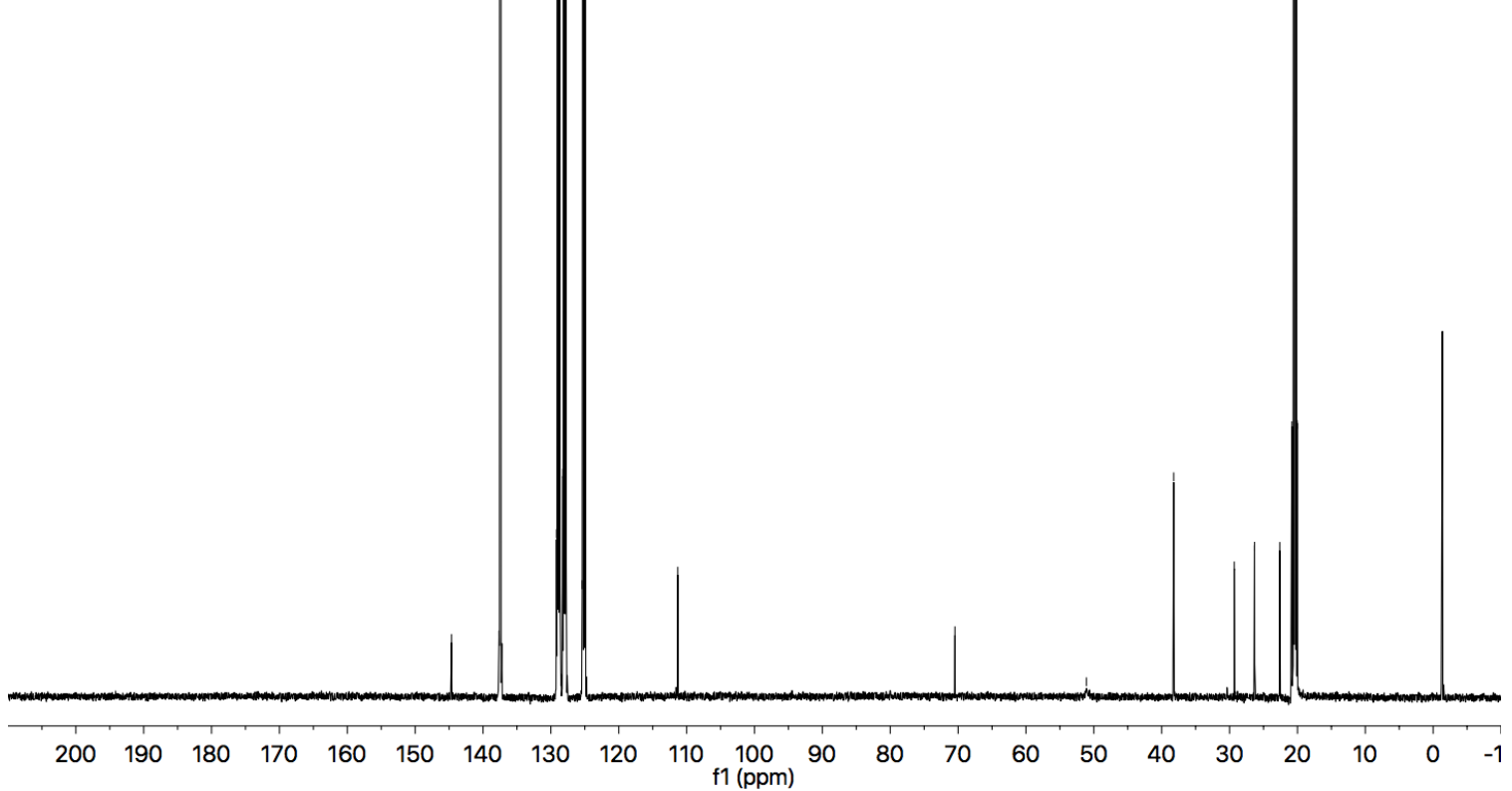

SI-23 


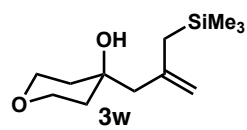

$\left(600 \mathrm{MHz},\left(\mathrm{CD}_{3}\right)_{2} \mathrm{CO}\right)$
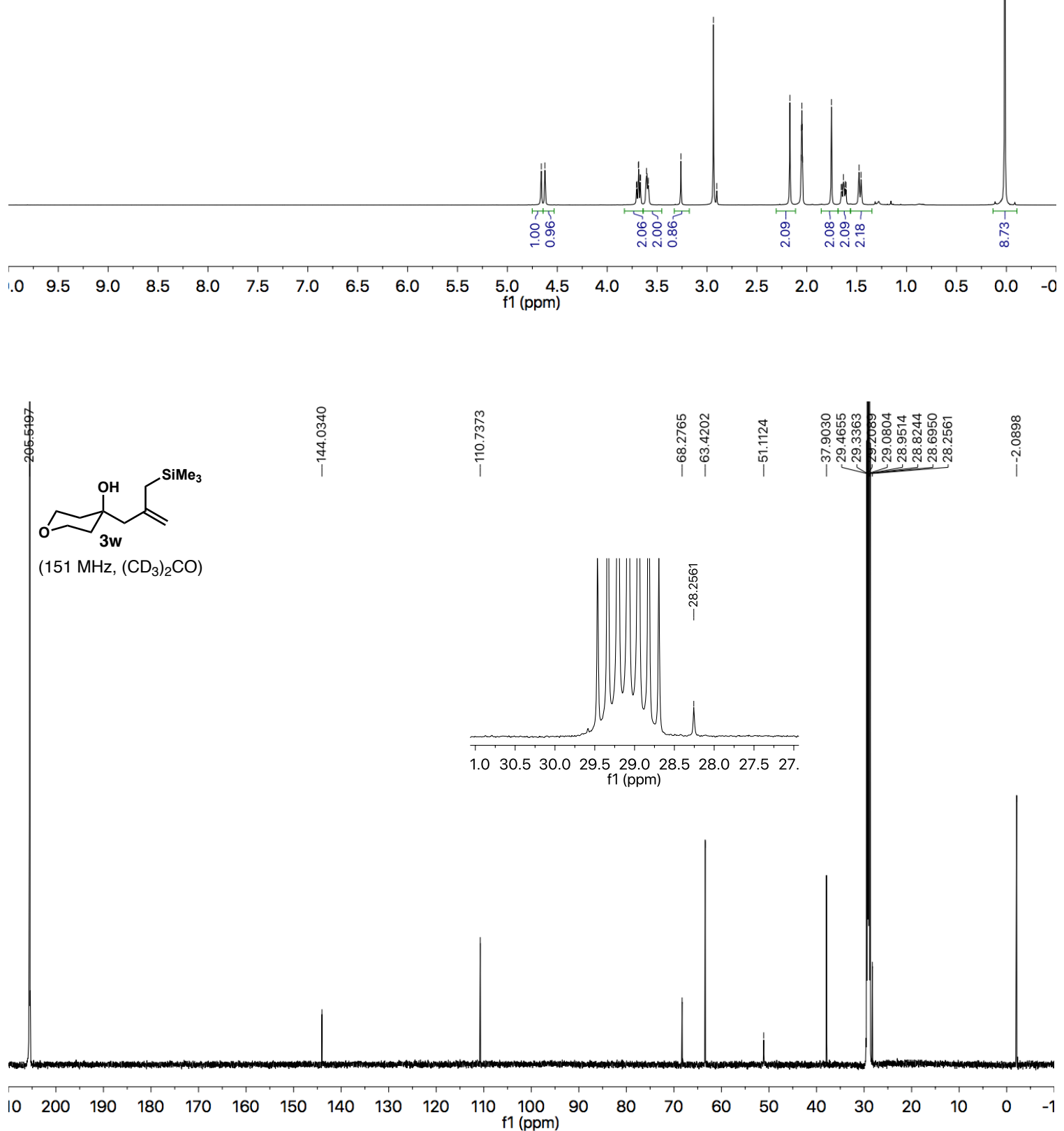

SI-24 

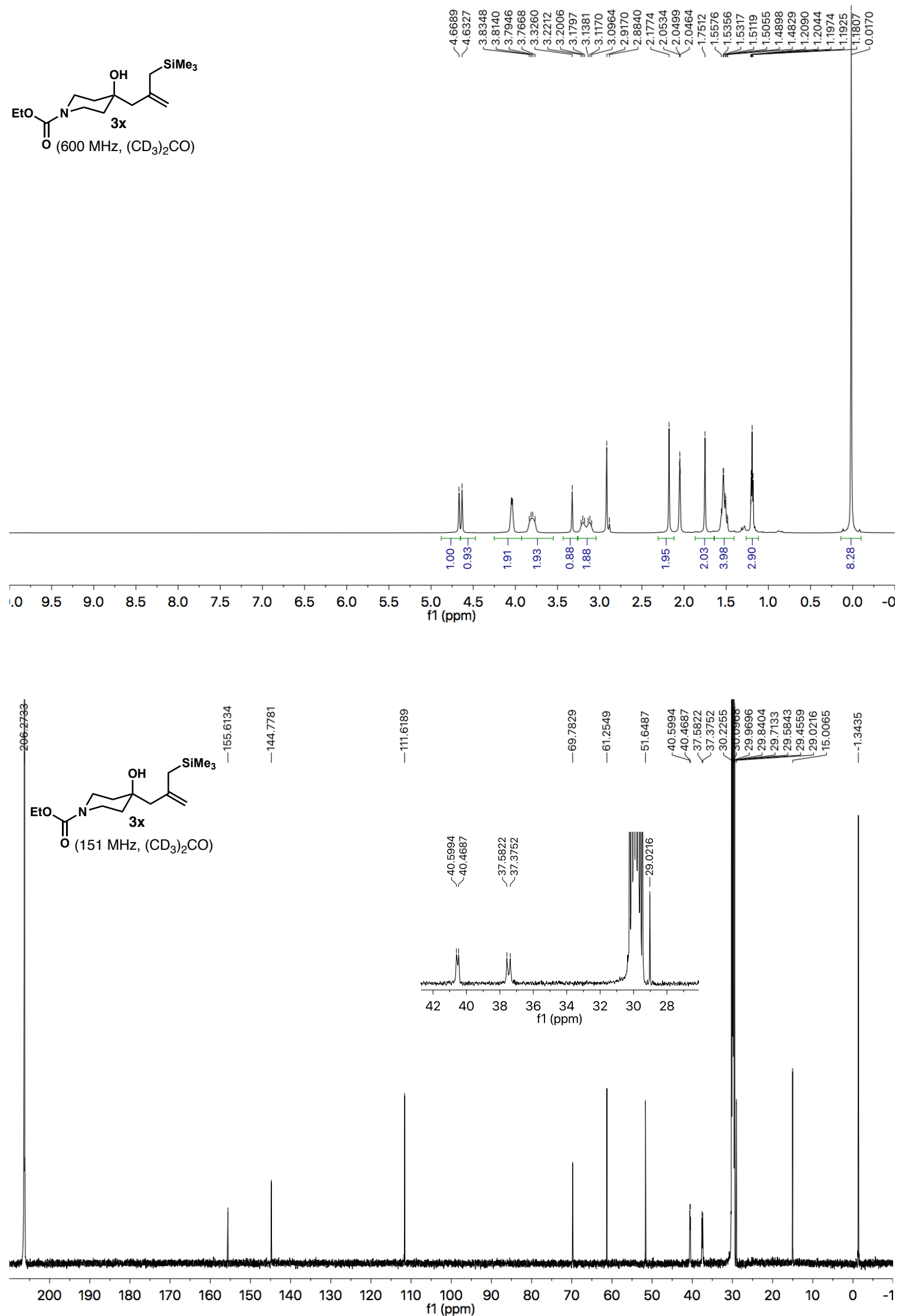

SI-25 


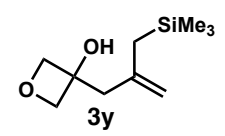

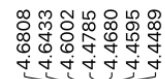

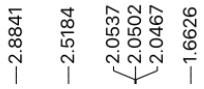

$\left(600 \mathrm{MHz},\left(\mathrm{CD}_{3}\right)_{2} \mathrm{CO}\right)$
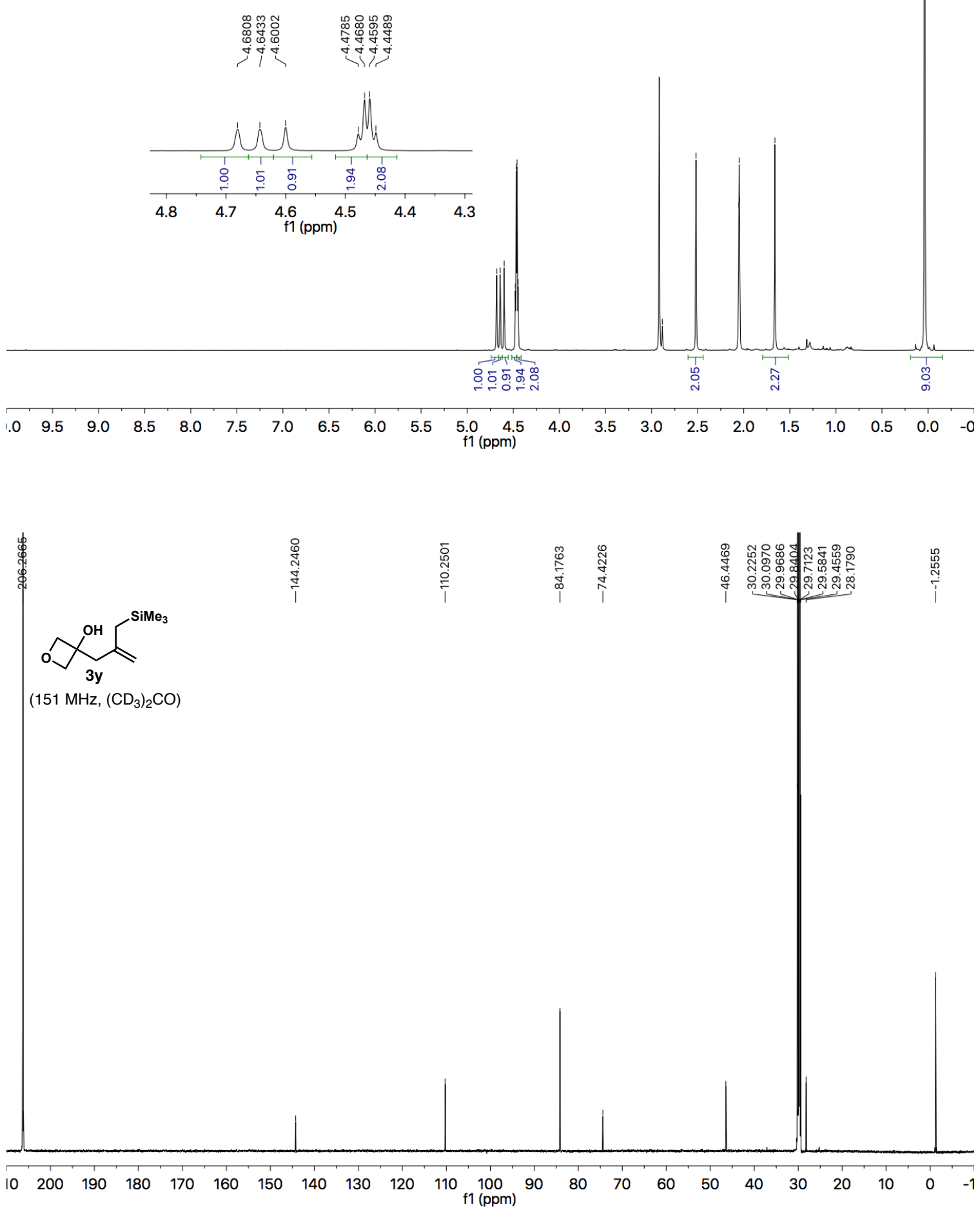

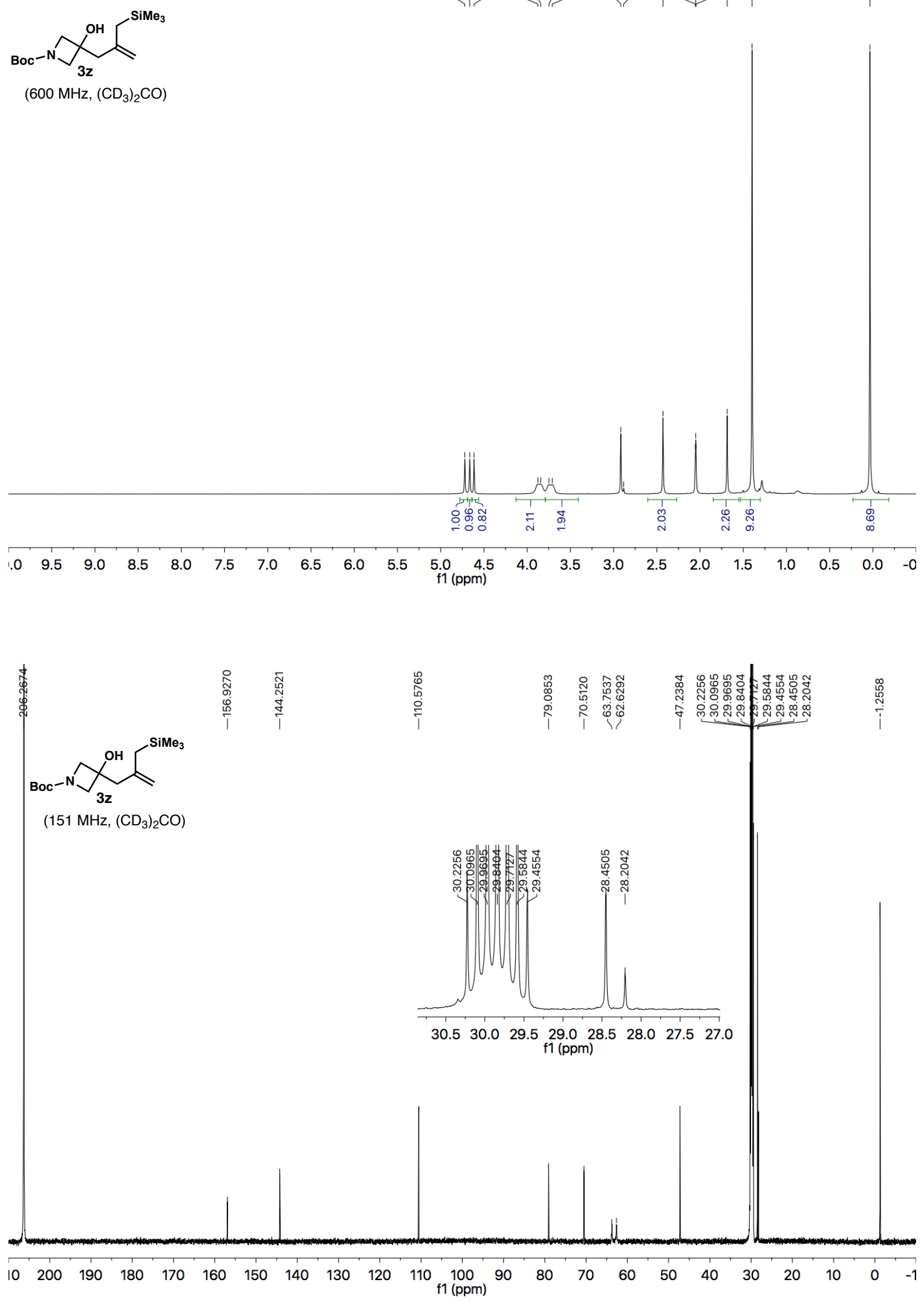

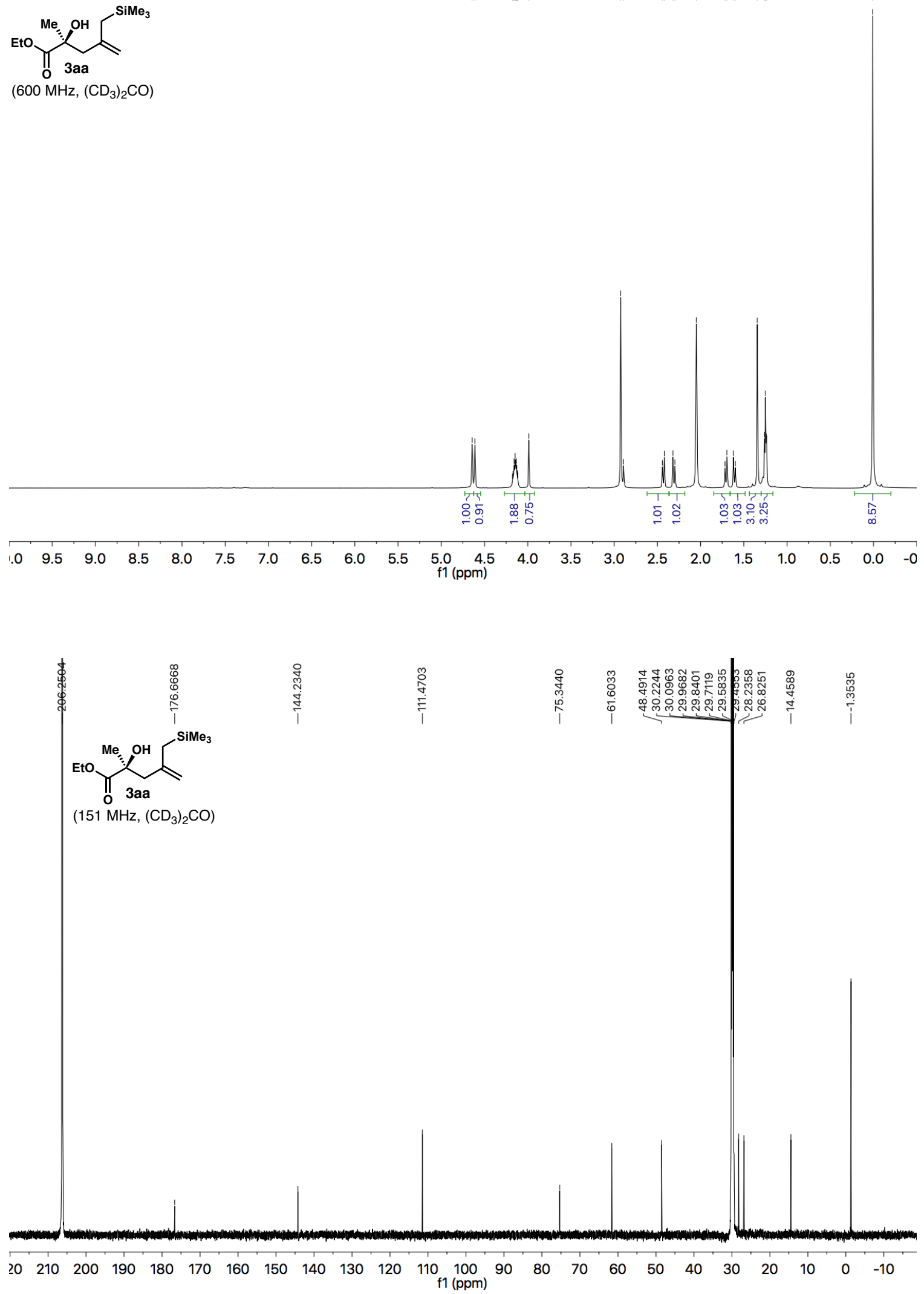


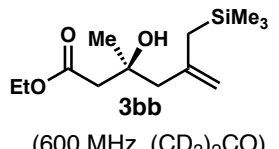

$\left(600 \mathrm{MHz},\left(\mathrm{CD}_{3}\right)_{2} \mathrm{CO}\right)$
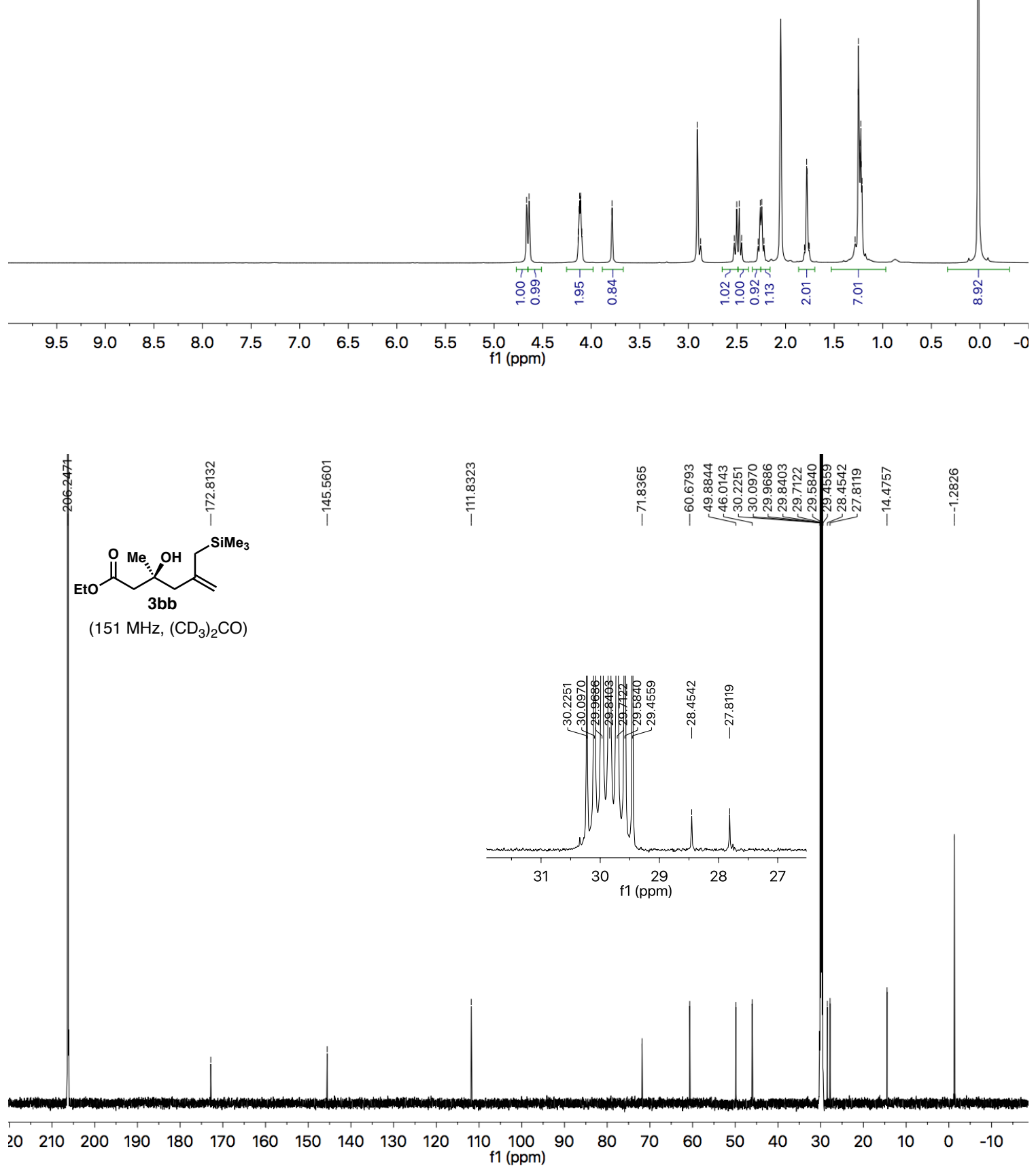

SI-29 

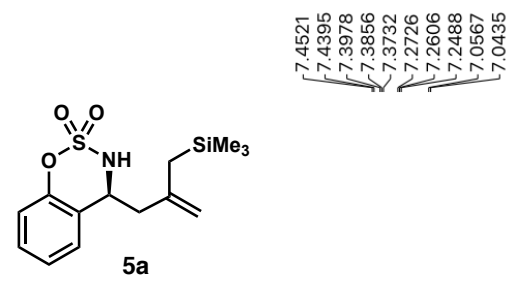

(600 MHz, $\left.\left(\mathrm{CD}_{3}\right)_{2} \mathrm{CO}\right)$
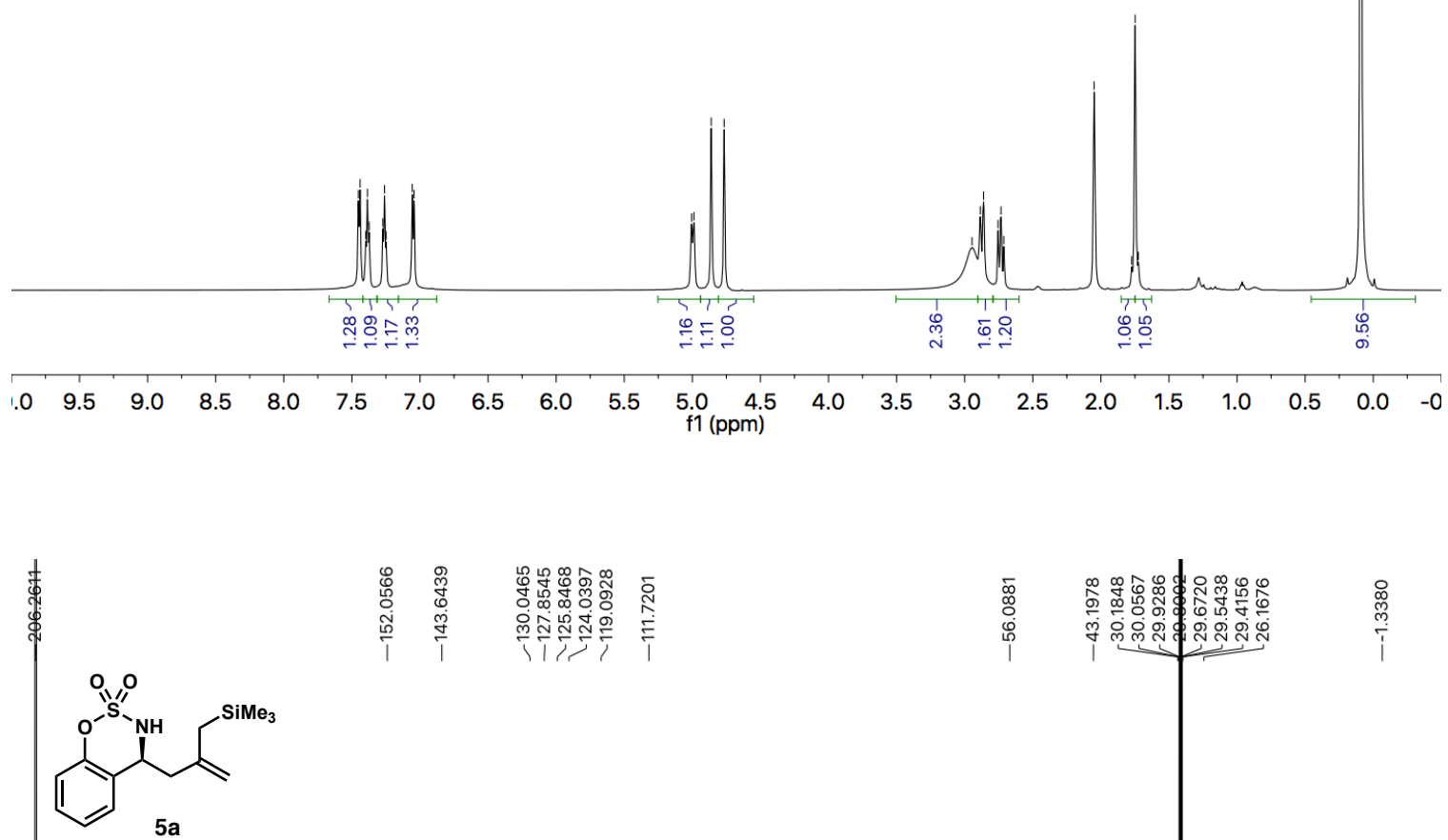

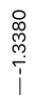

(151 MHz, $\left.\left(\mathrm{CD}_{3}\right)_{2} \mathrm{CO}\right)$

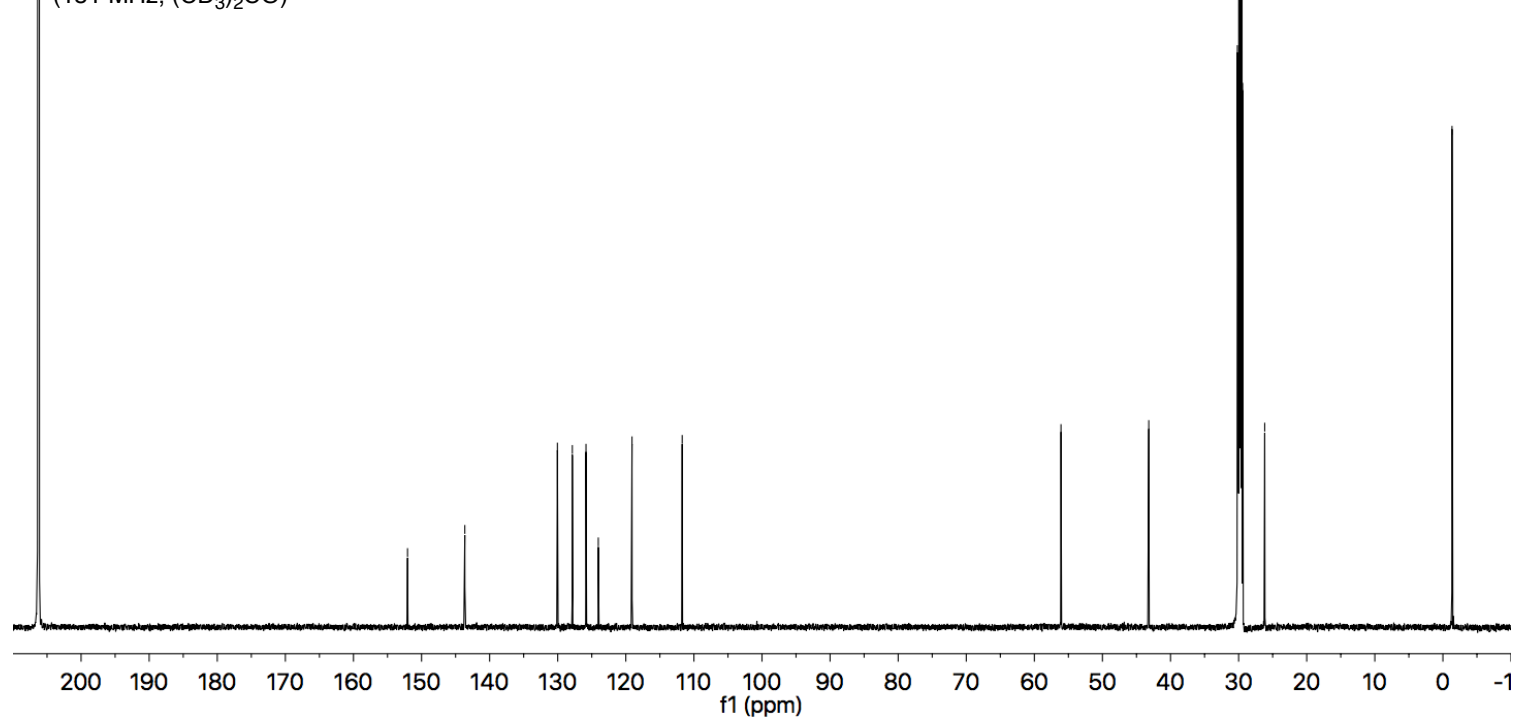

SI-30 

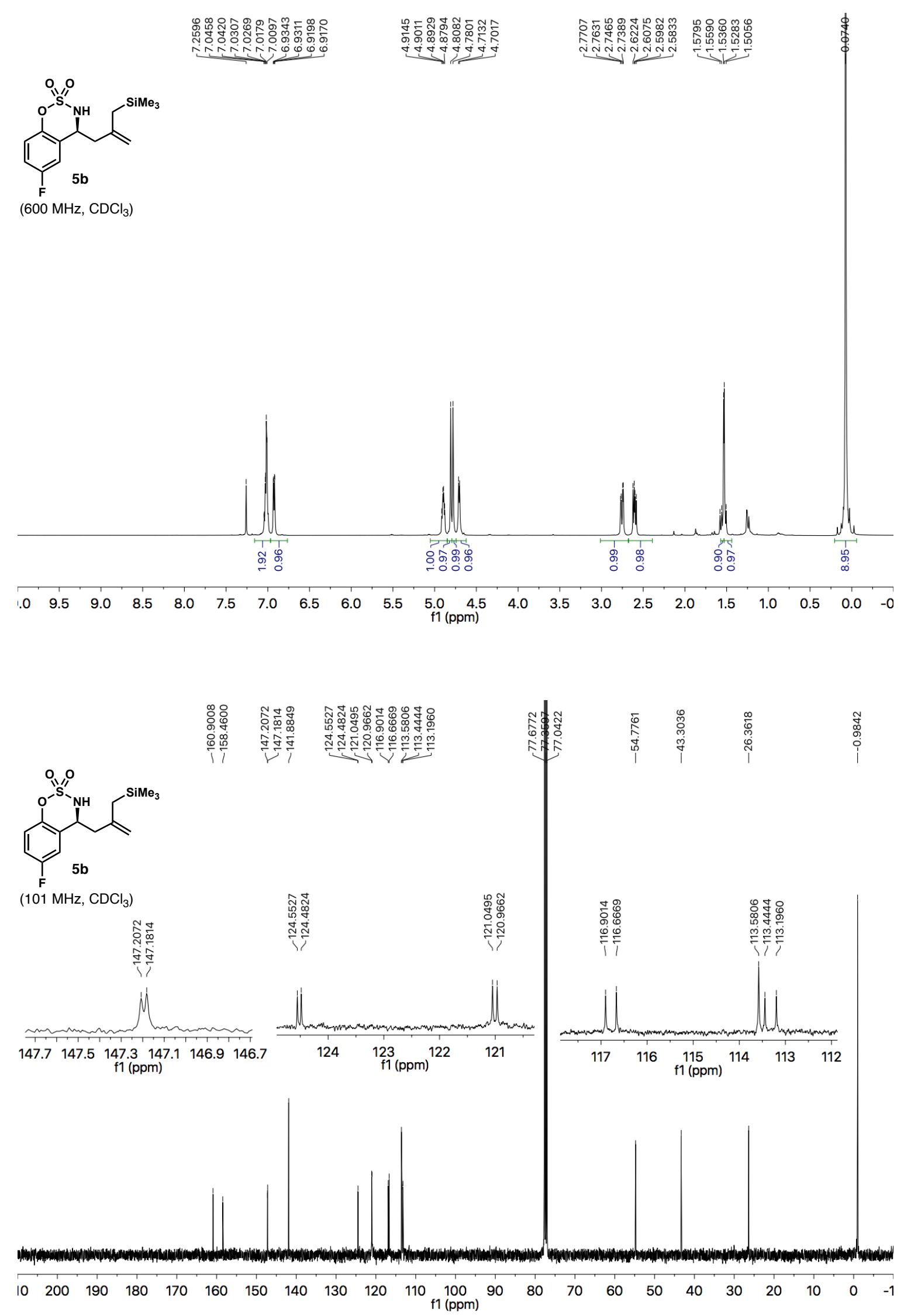

SI-31 

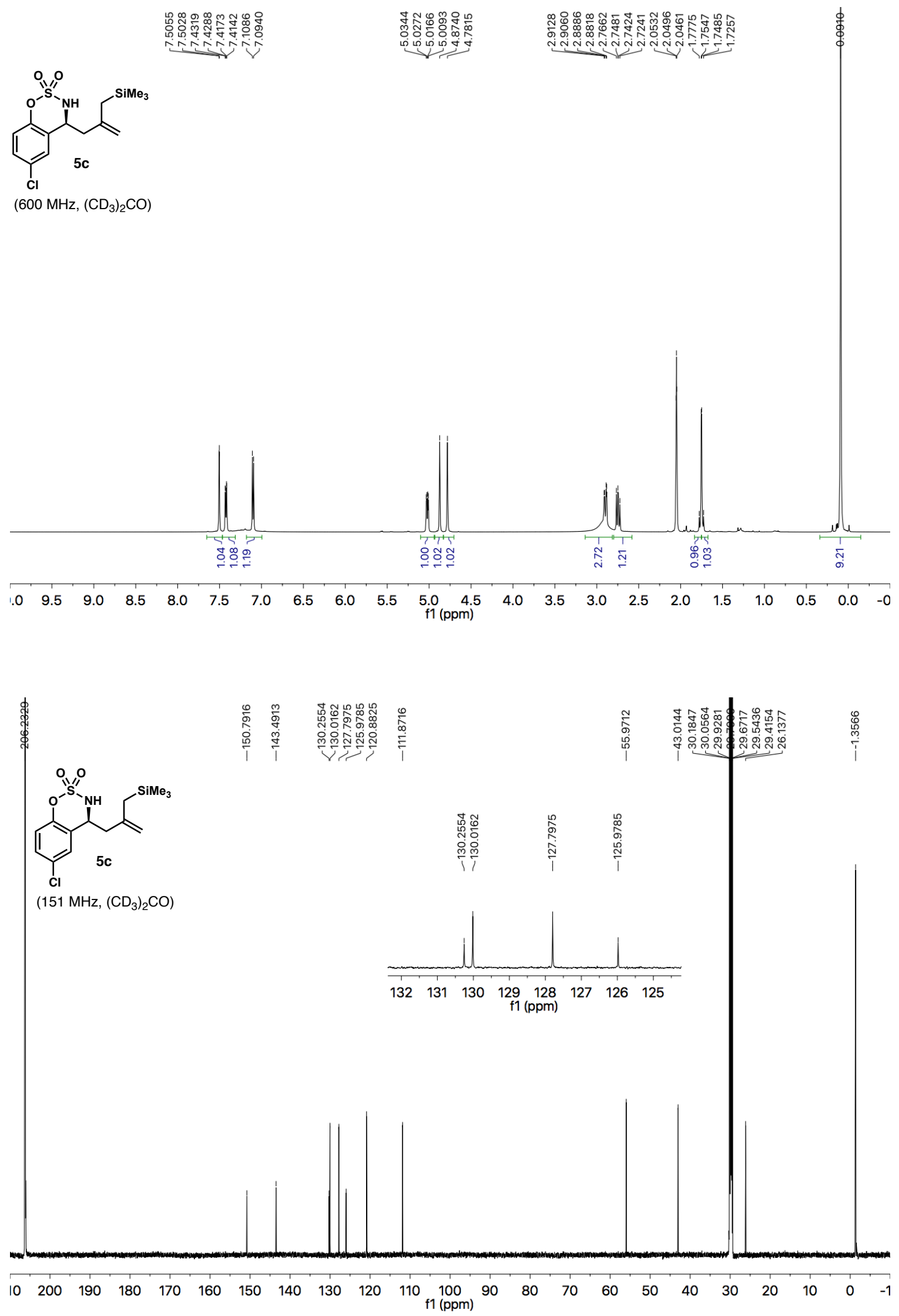

SI-32 

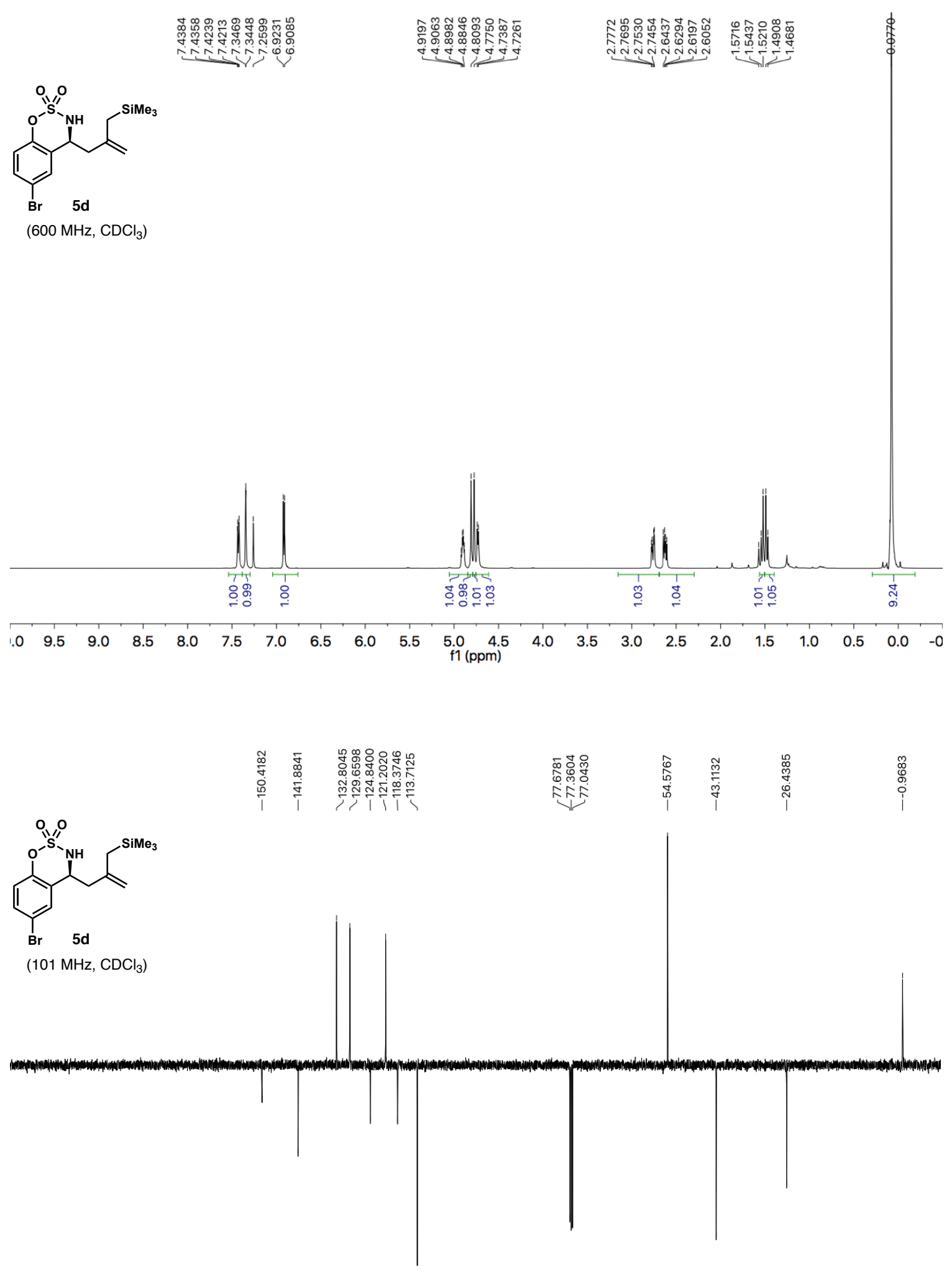

$\begin{array}{llllllllllllllllllllll}10 & 200 & 190 & 180 & 170 & 160 & 150 & 140 & 130 & 120 & 110 \begin{array}{c}100 \\ \mathrm{f} 1(\mathrm{ppm})\end{array} & 90 & 80 & 70 & 60 & 50 & 40 & 30 & 20 & 10 & 0 & -1\end{array}$ 

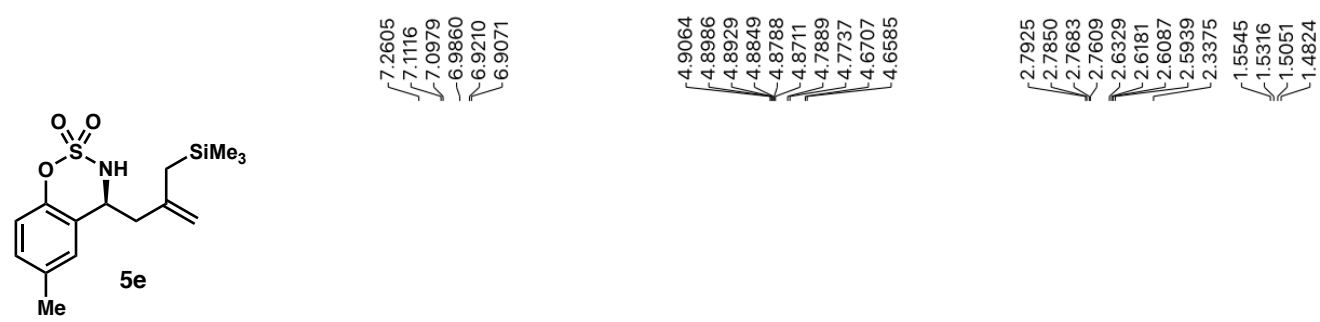

(600 MHz, $\mathrm{CDCl}_{3}$ )
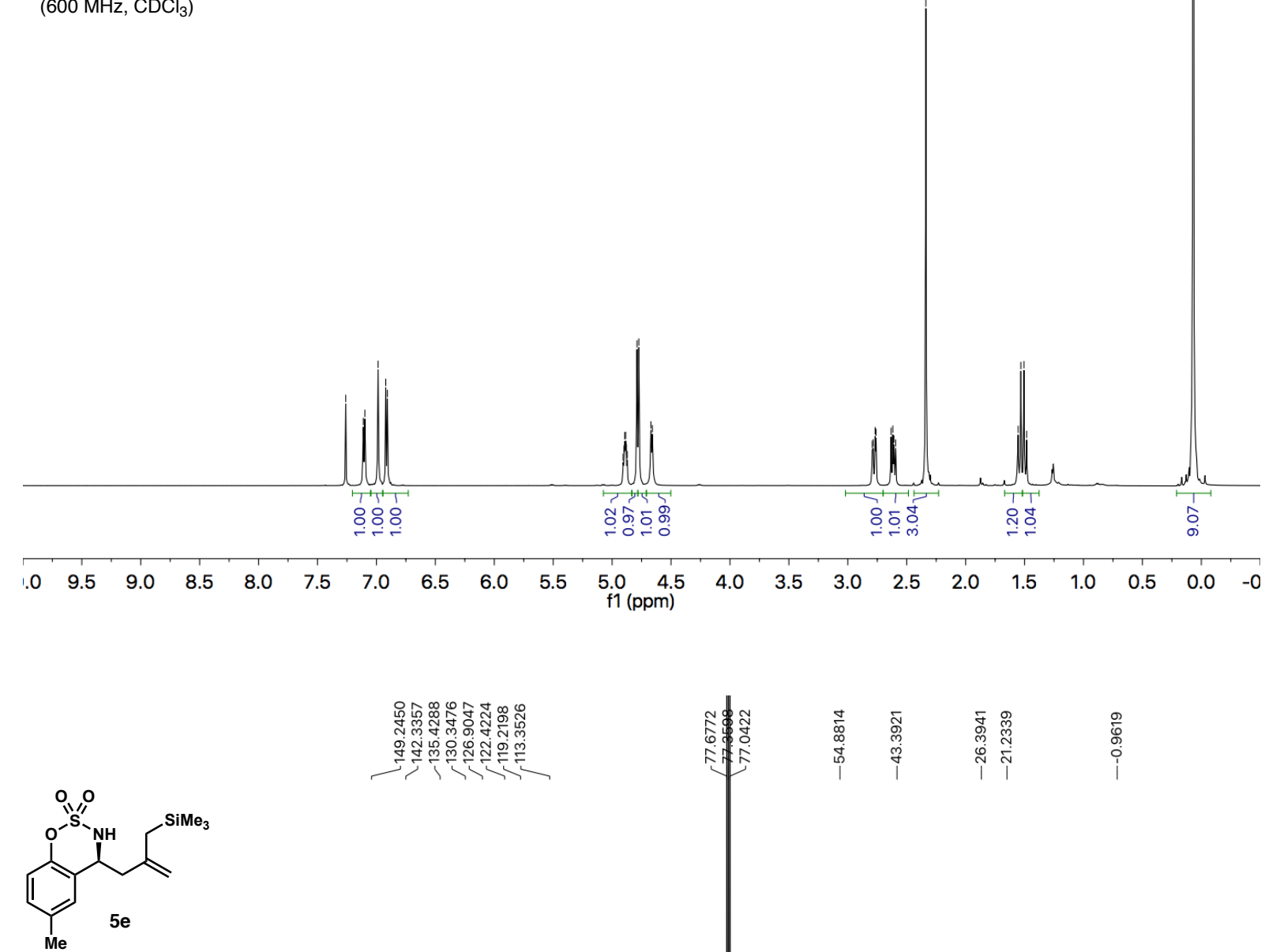

(101 MHz, $\mathrm{CDCl}_{3}$ )

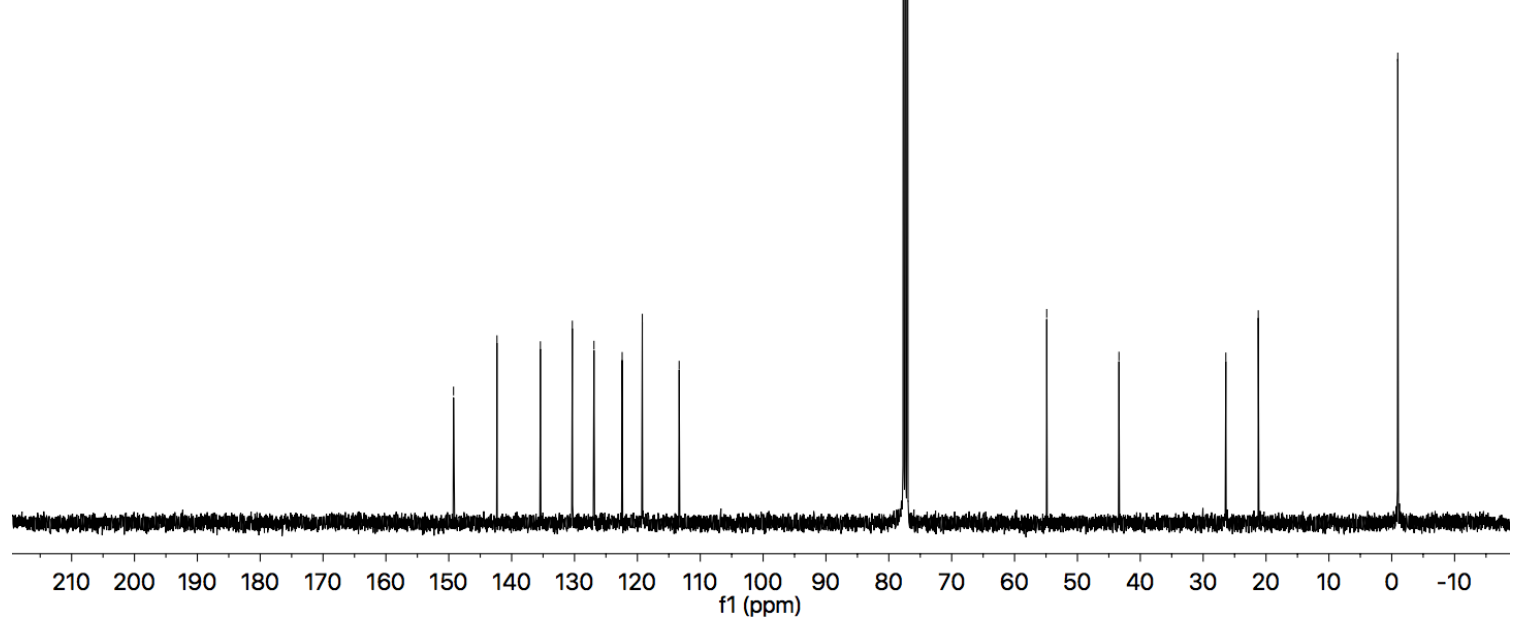

SI-34 

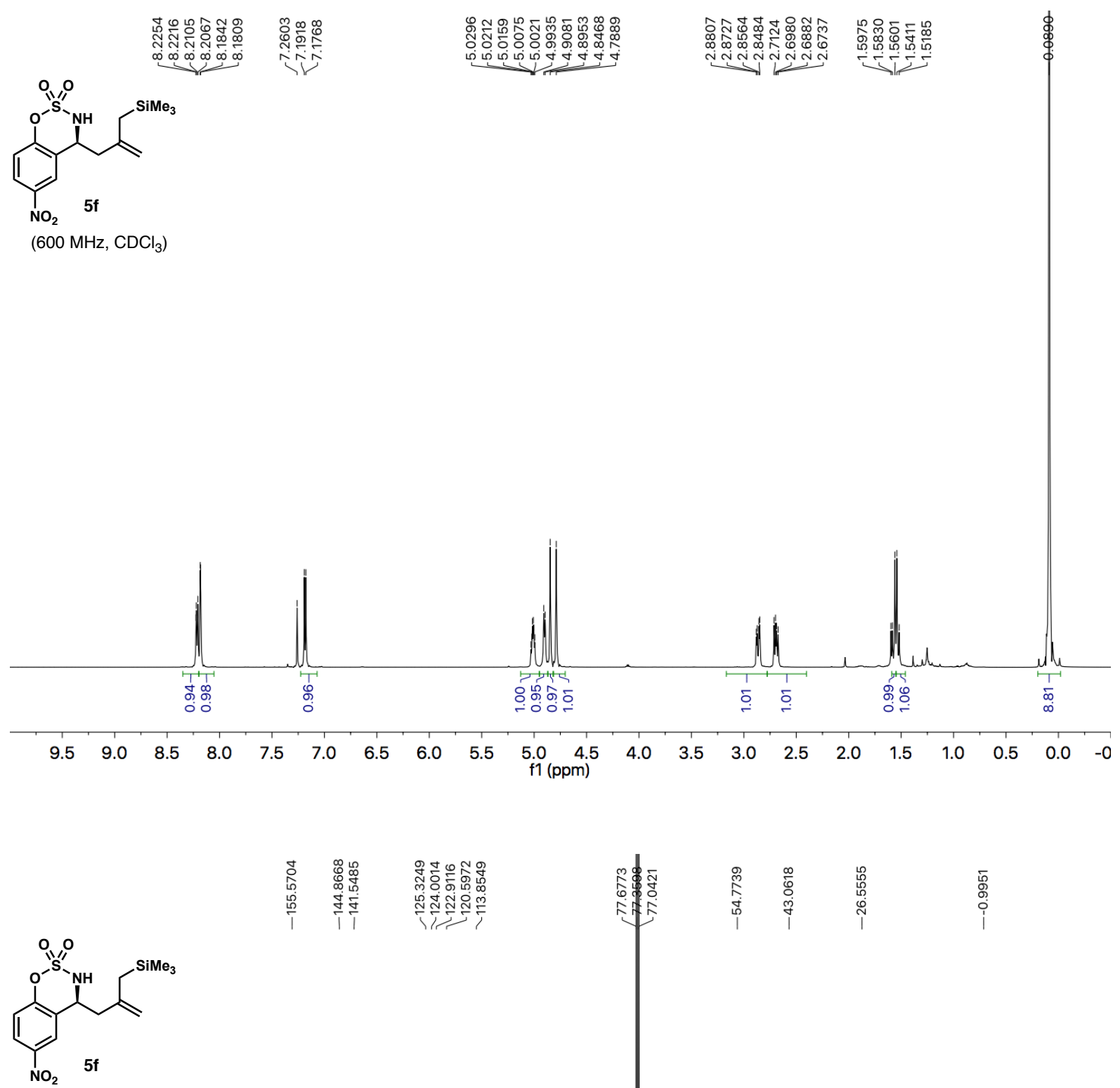

$\left(101 \mathrm{MHz}, \mathrm{CDCl}_{3}\right.$ )

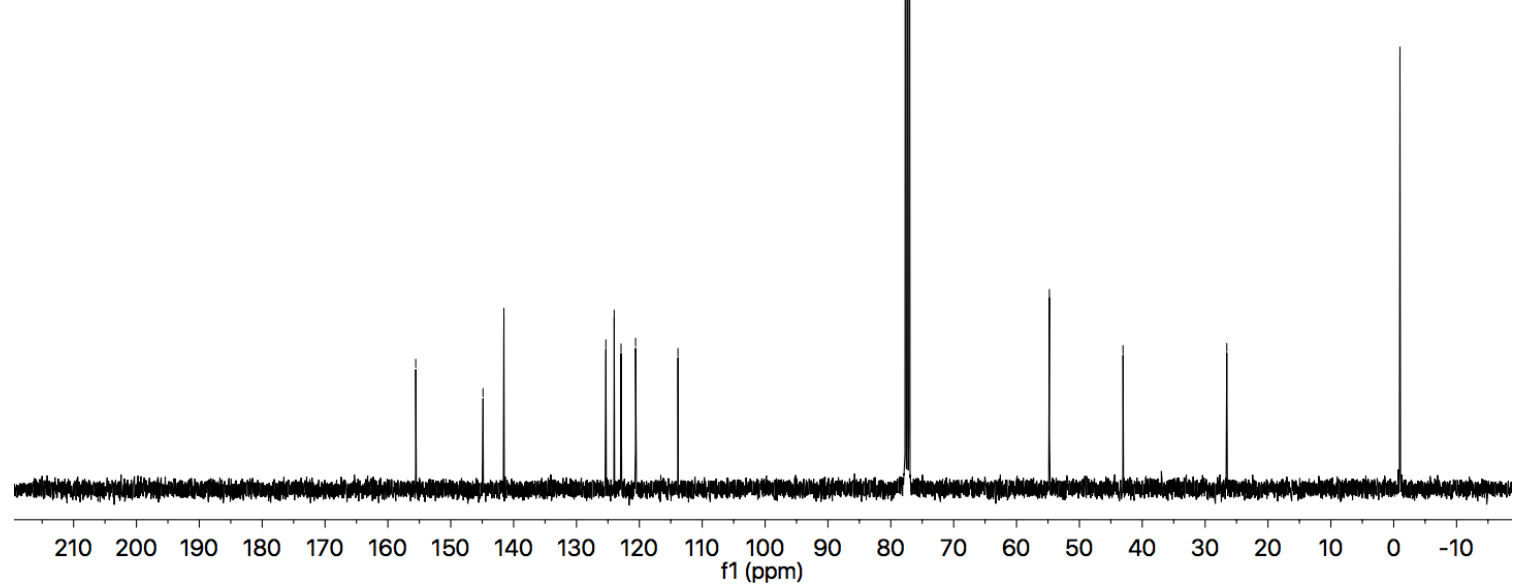

SI-35 

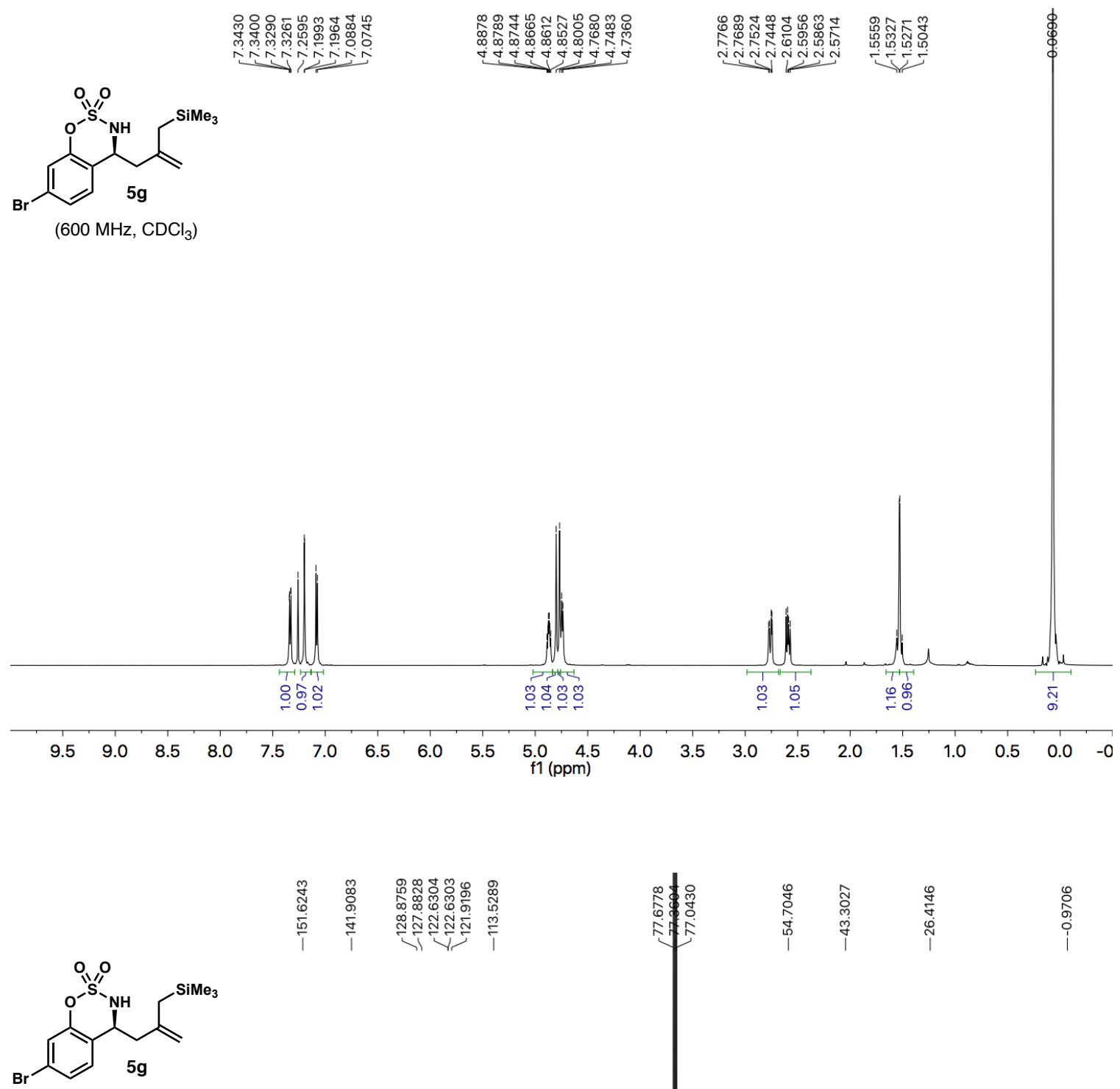

$\left(101 \mathrm{MHz}, \mathrm{CDCl}_{3}\right.$ )
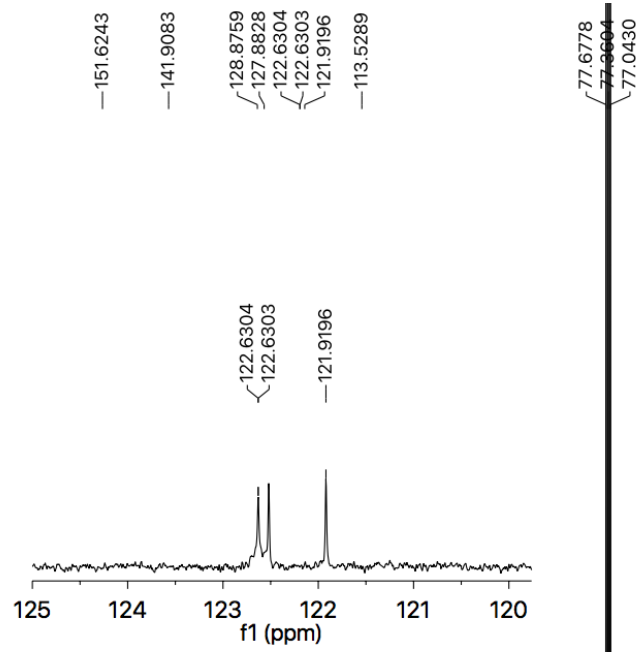

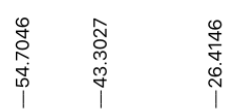

0
$\vdots$
0
0
0

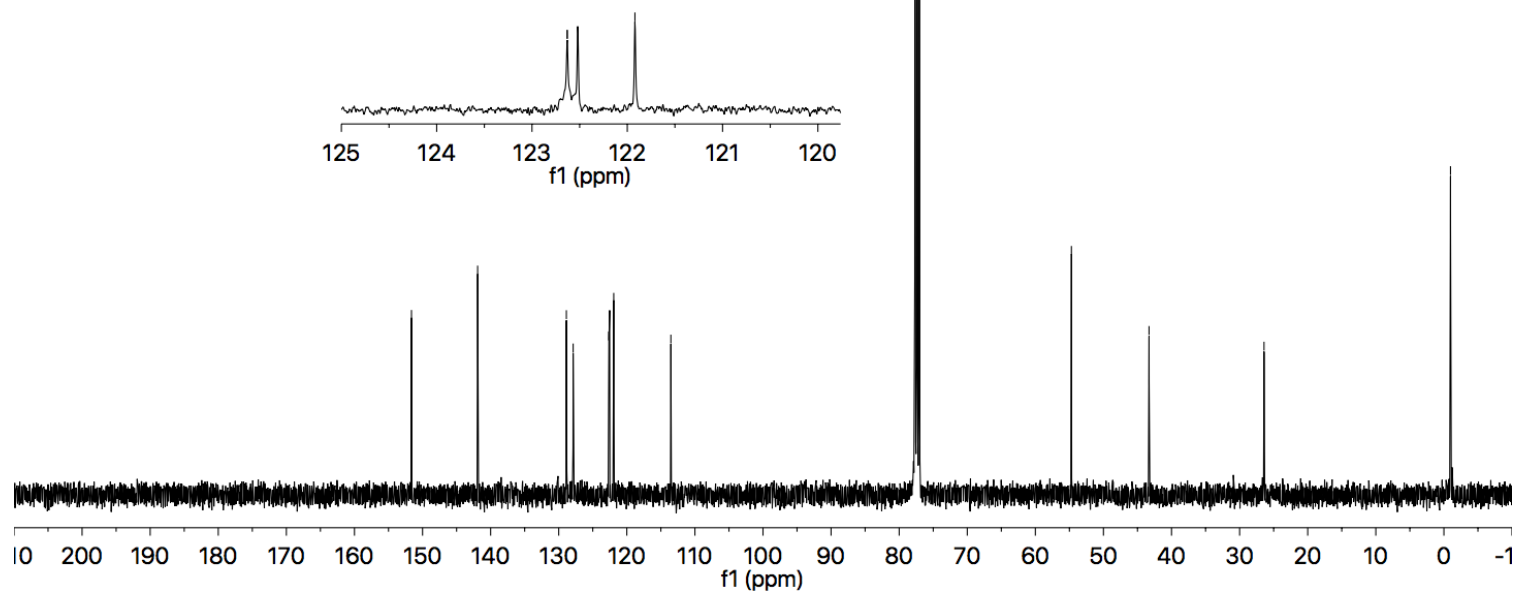



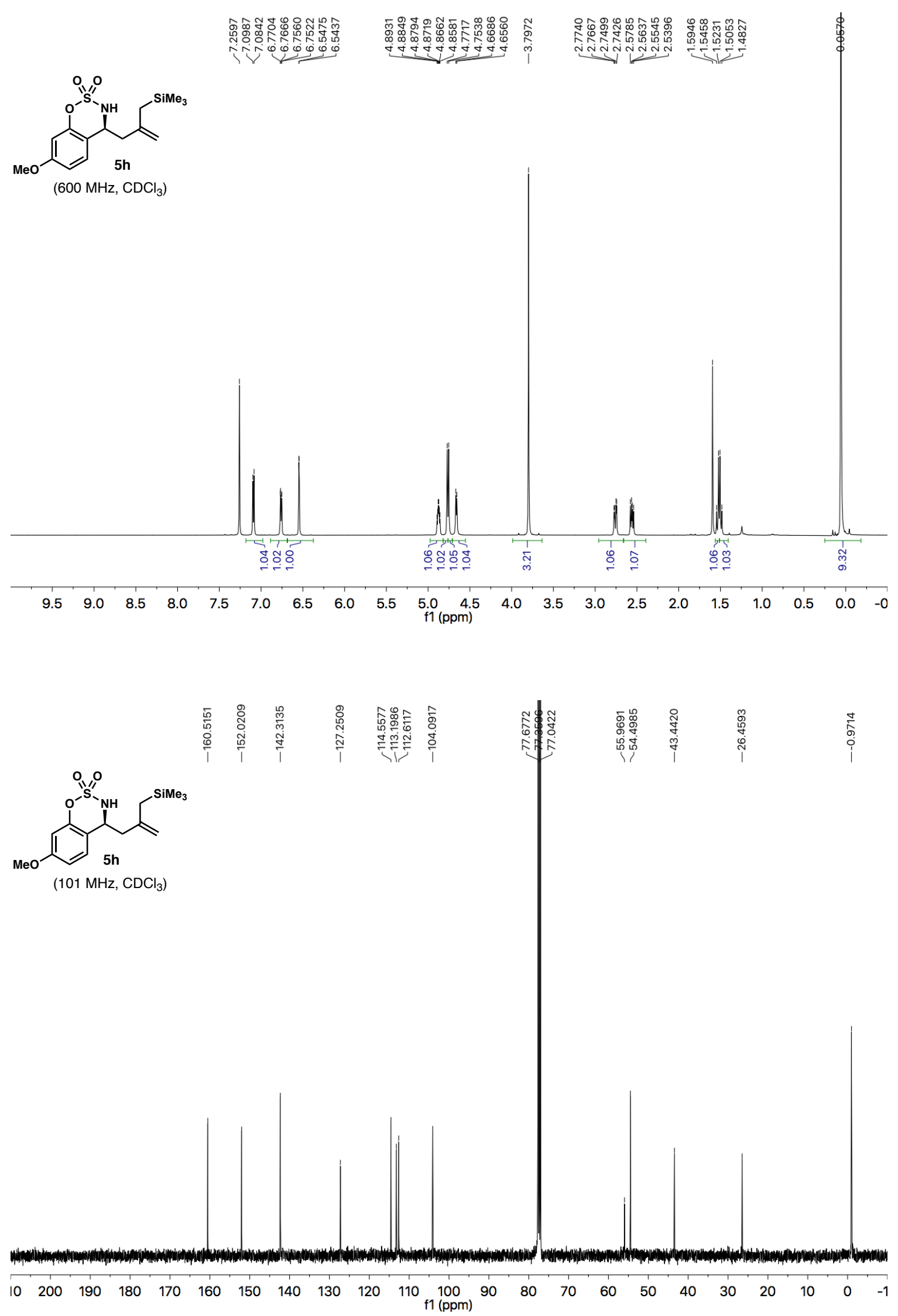

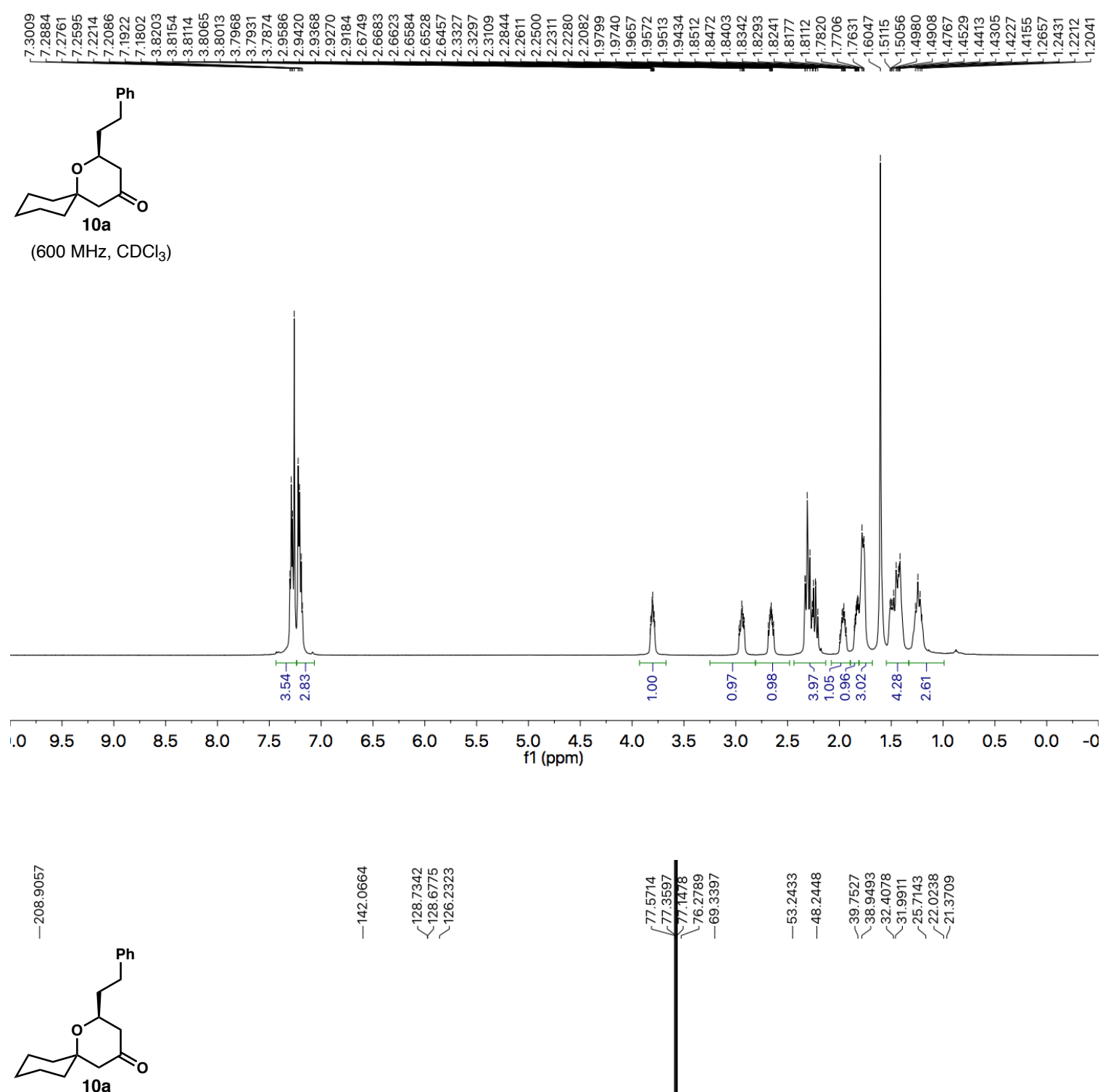

(151 MHz, $\mathrm{CDCl}_{3}$ )

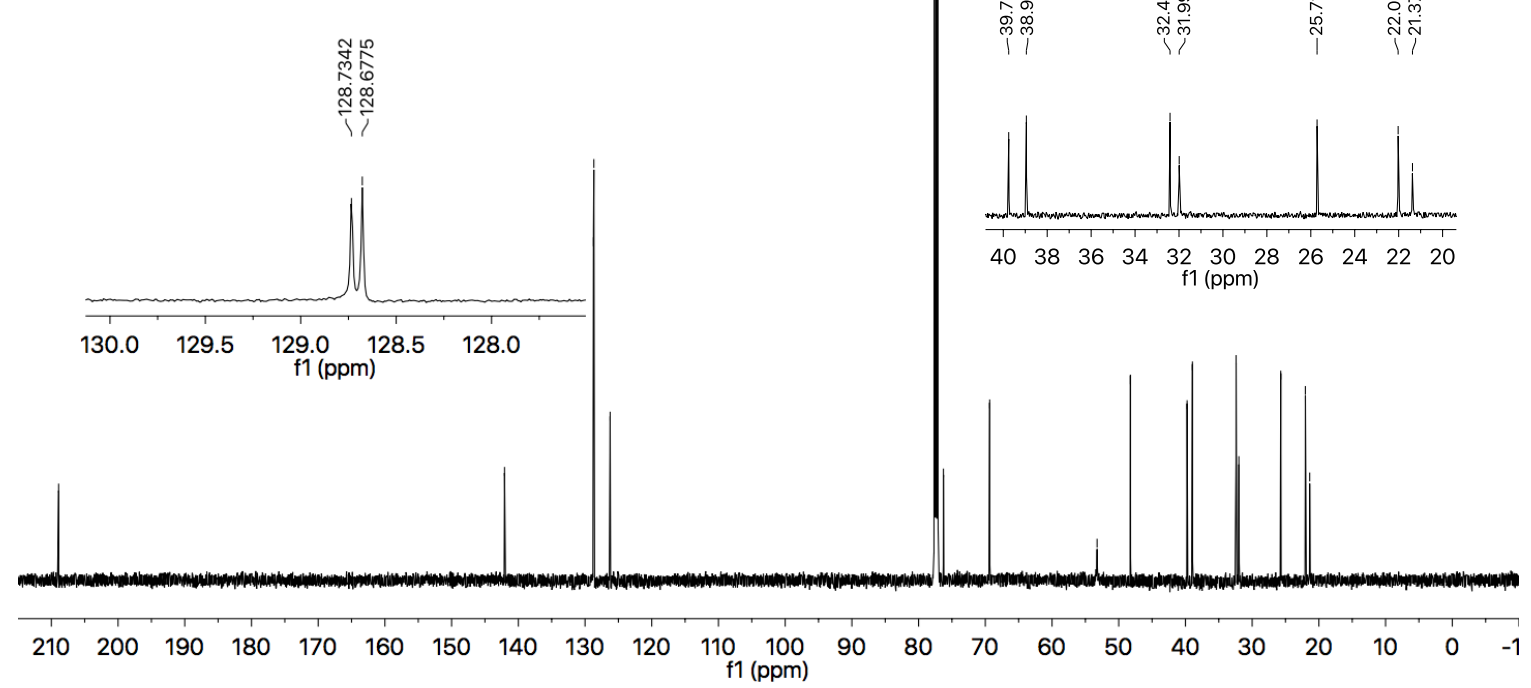



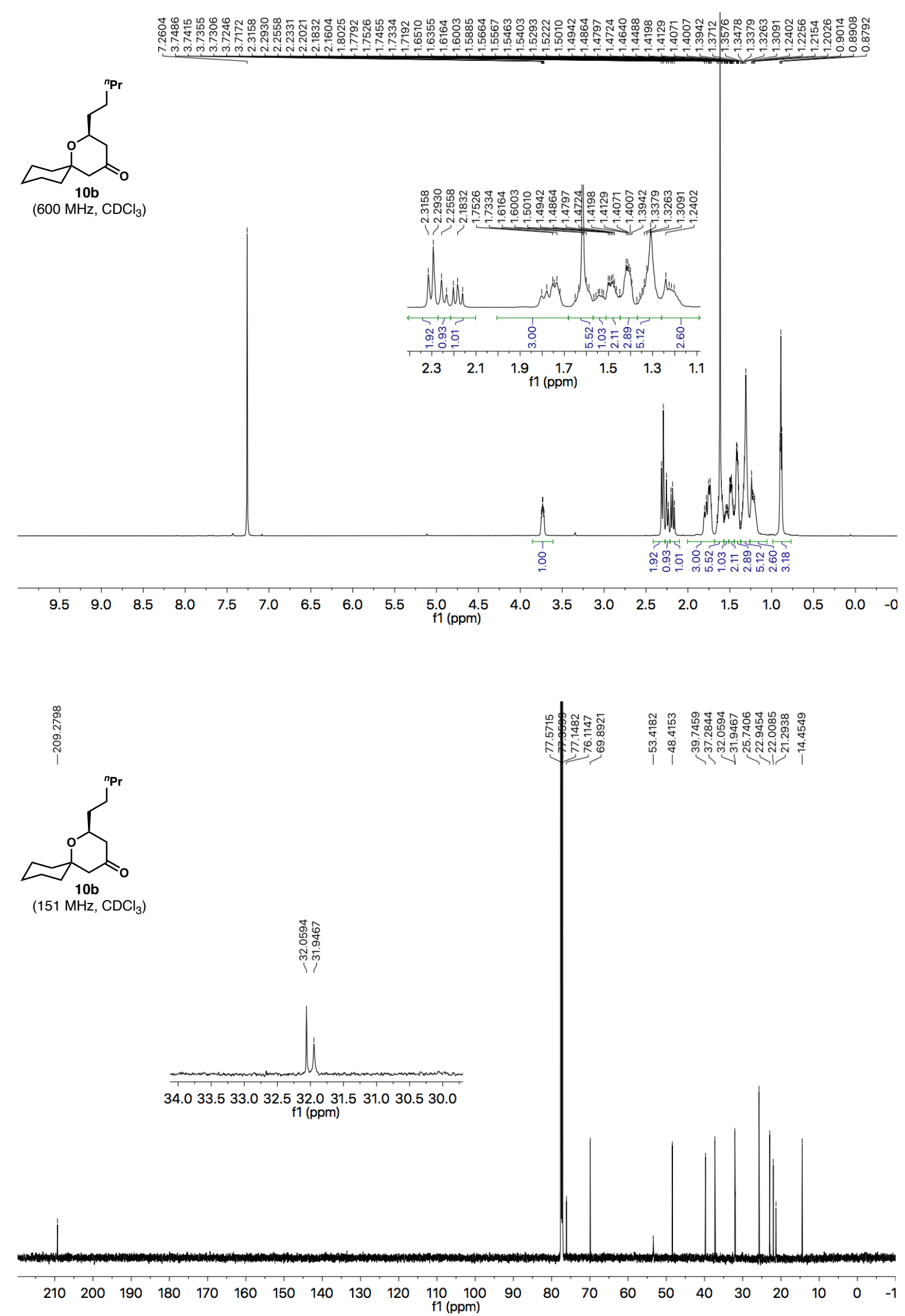

SI-39 

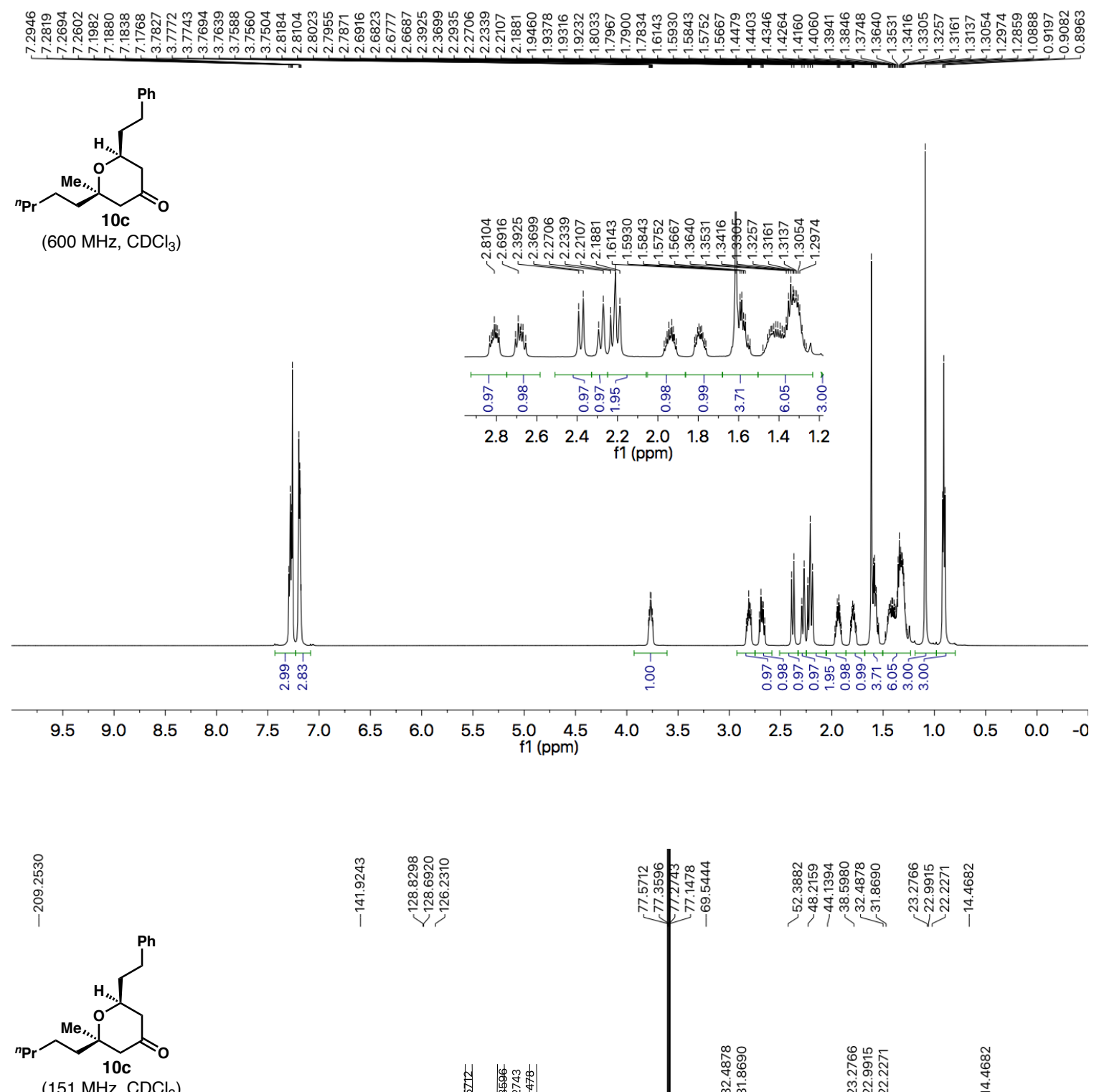

(151 $\mathrm{MHz}, \mathrm{CDCl}_{3}$ ) 

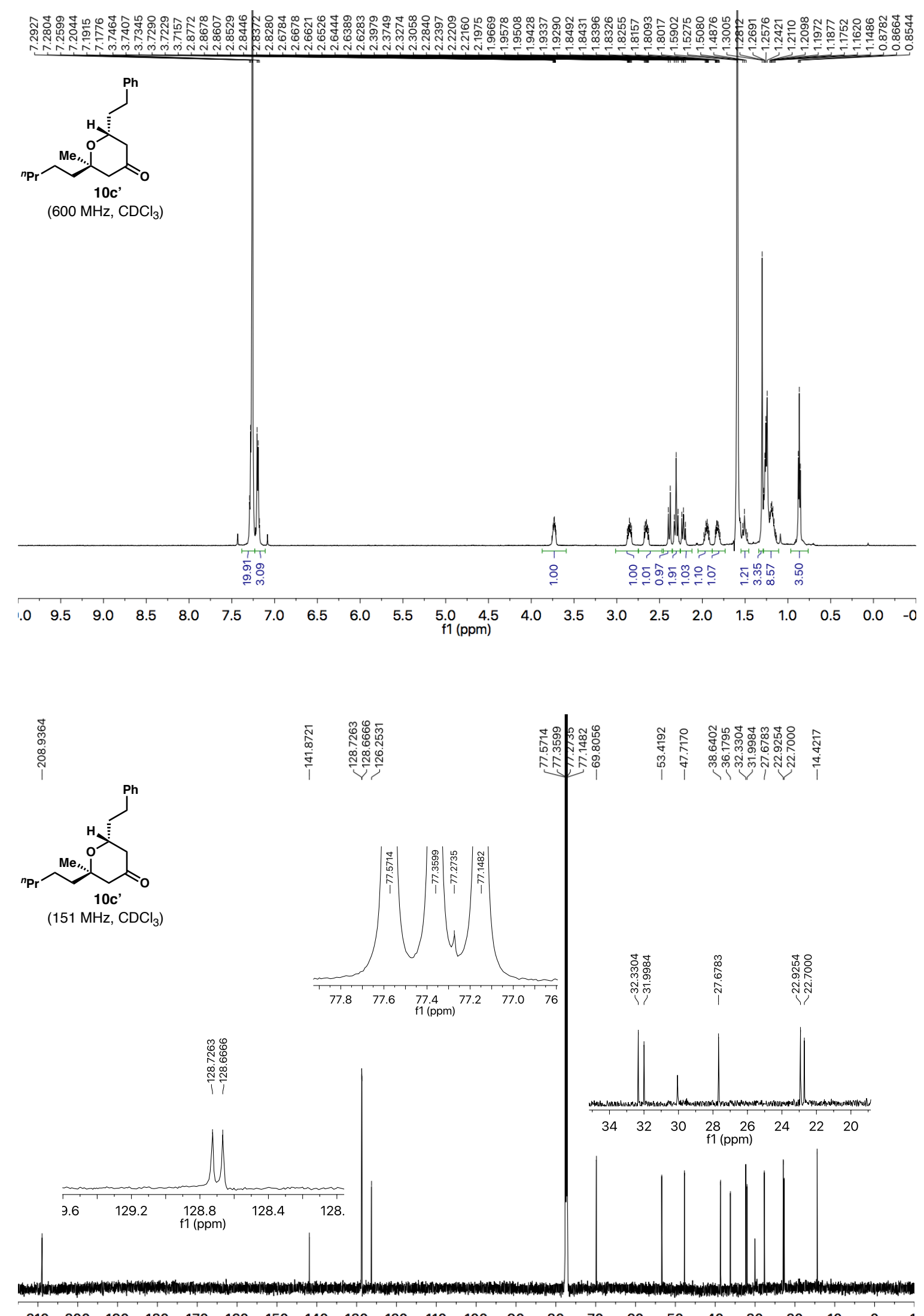

$\begin{array}{llllllllllllllllllllll}210 & 200 & 190 & 180 & 170 & 160 & 150 & 140 & 130 & 120 & \begin{array}{c}110 \\ \mathrm{f} 1(\mathrm{ppm})\end{array} & 90 & 80 & 70 & 60 & 50 & 40 & 30 & 20 & 10 & 0 & -1\end{array}$ 


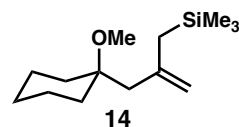

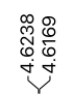

$\left(600 \mathrm{MHz},\left(\mathrm{CD}_{3}\right)_{2} \mathrm{CO}\right)$
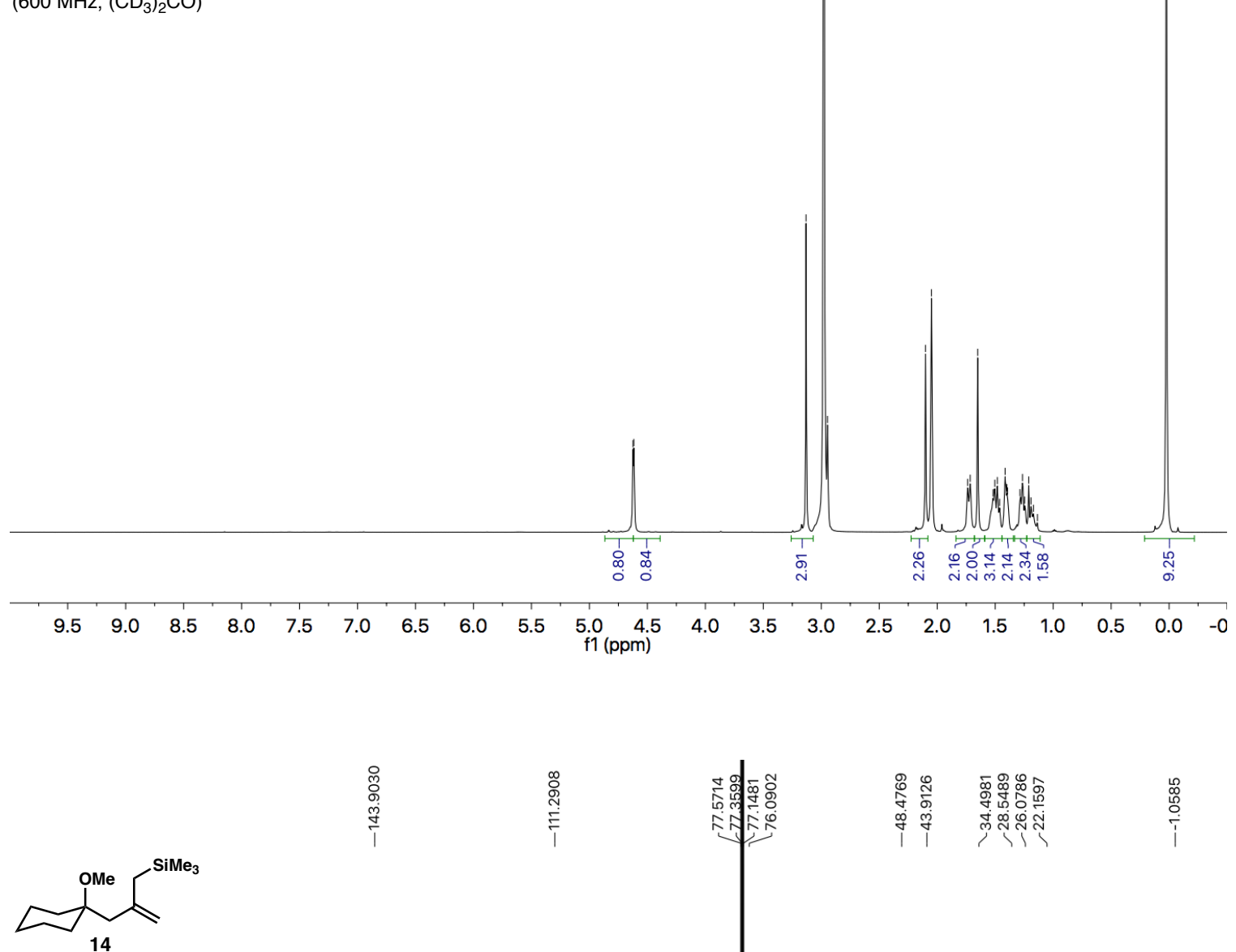

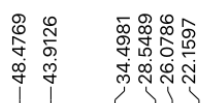

$\left(151 \mathrm{MHz},\left(\mathrm{CD}_{3}\right)_{2} \mathrm{CO}\right)$

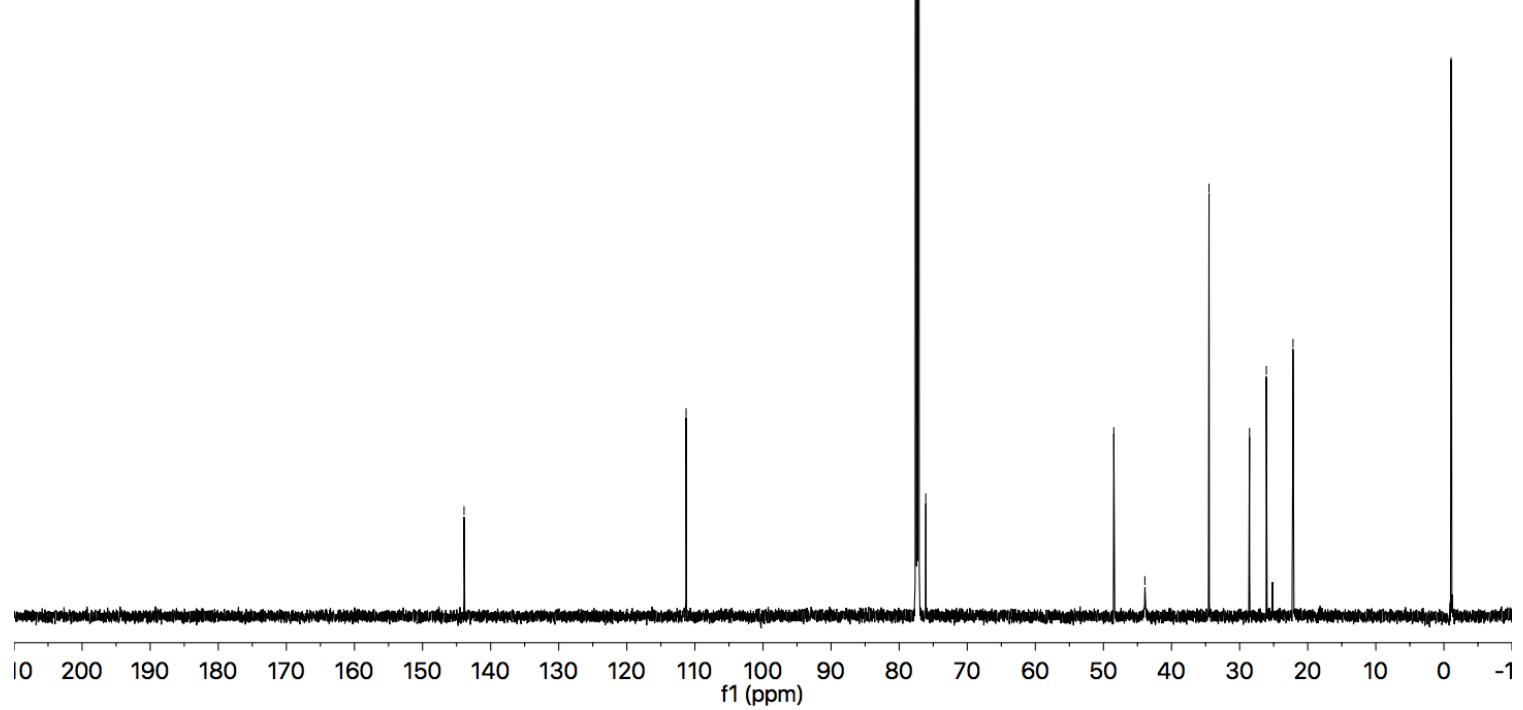

SI-42 

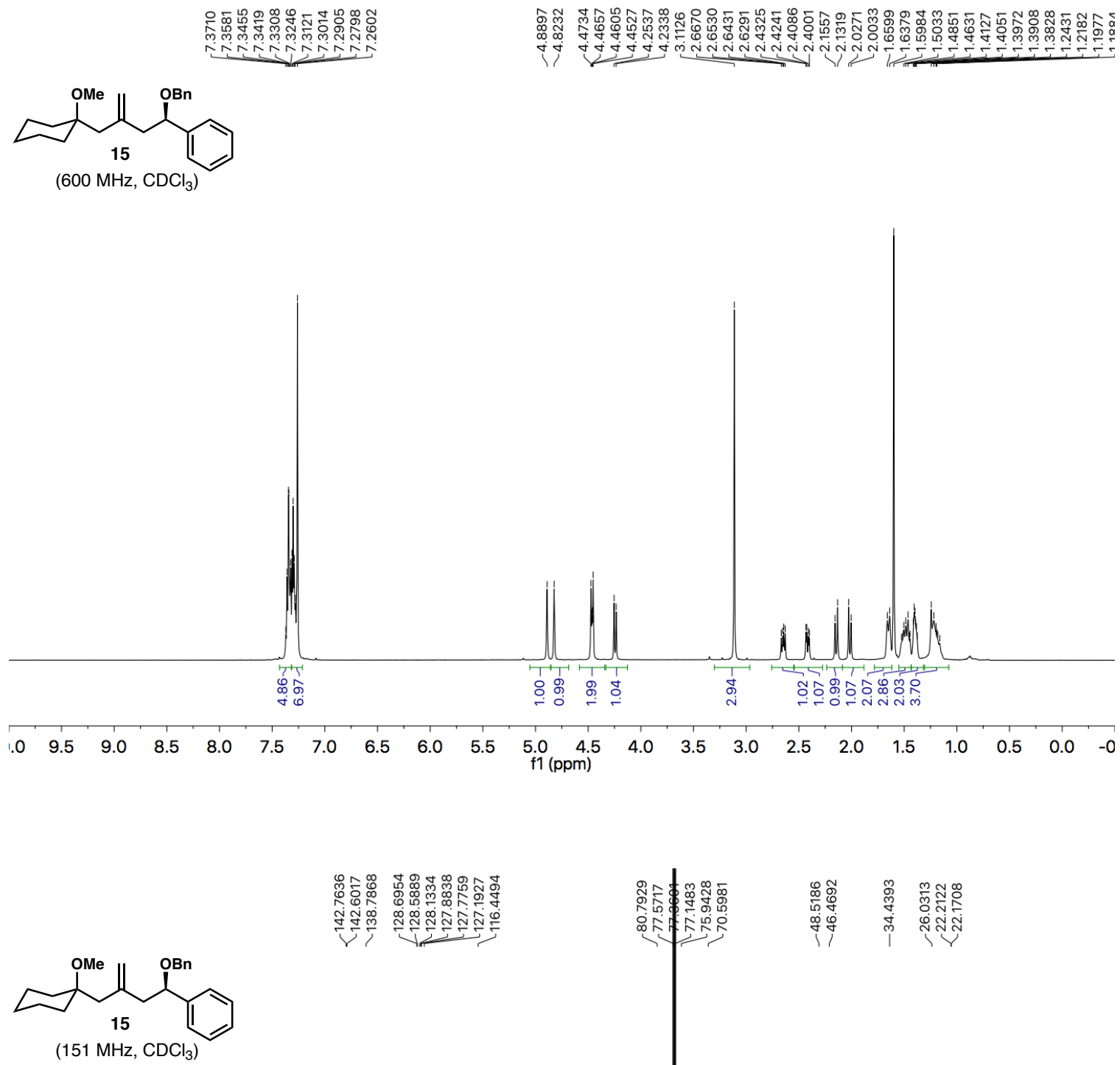

(151 MHz, $\mathrm{CDCl}_{3}$ )

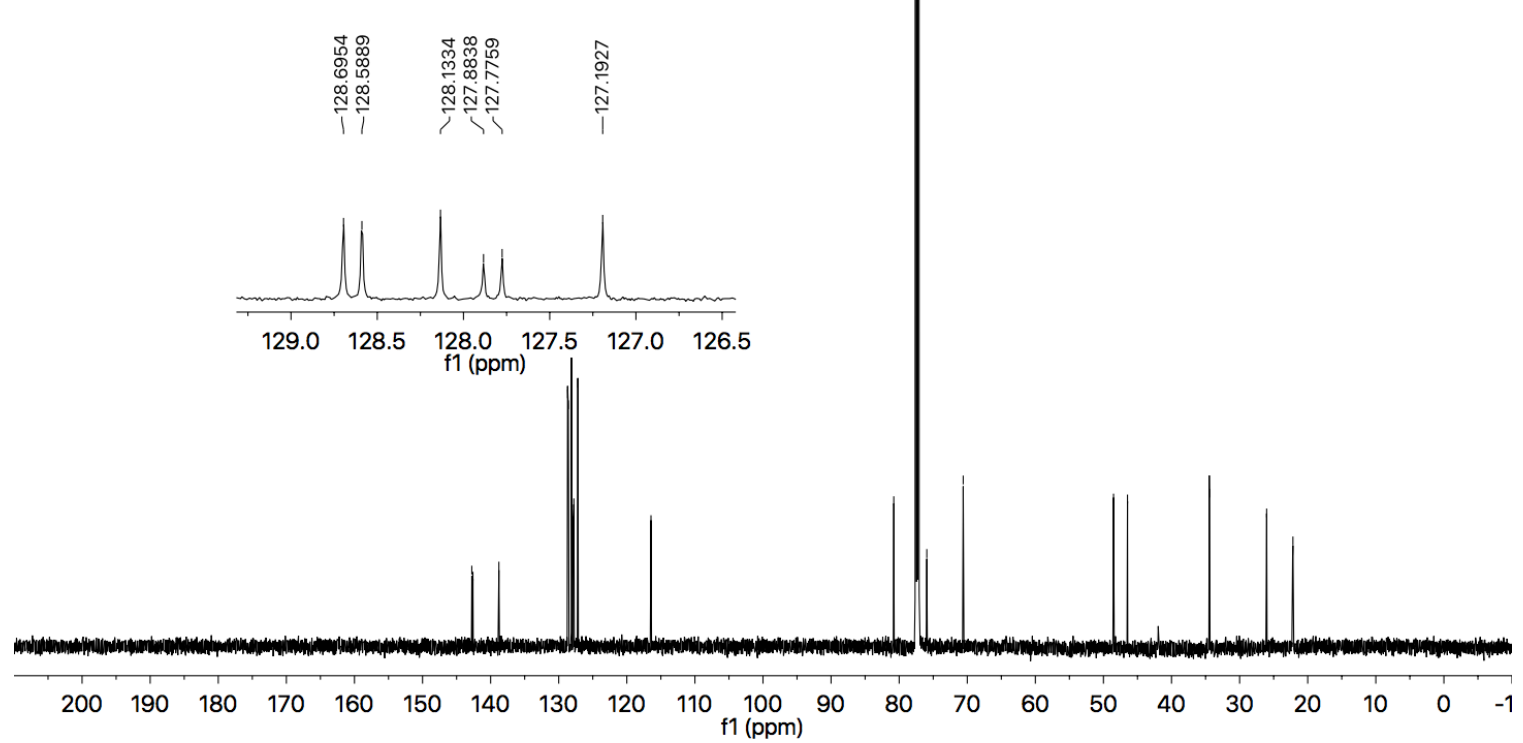

